Çukurova Üniversitesi Eğitim Fakültesi Dergisi

Vol: 46 No:1 pp: 39-84

\title{
Reflection of Explicit-Reflective Argumentation Based and Explicit- Reflective Nature of Science Teaching on Prospective Science Teachers' Written Arguments
}

\author{
Emrah HíĞDE ${ }^{\mathrm{a}^{*}}$, Hilal AKTAMIŞ ${ }^{\mathrm{a}}$
}

${ }^{a}$ Adnan Menderes Üniversitesi, Eğitim Fakültesi, Aydın/Türkiye

\section{Article Info}

DOI: $10.14812 /$ cufej.309431

Keywords:

Argumentation,

explicit-reflective,

nature of science,

written argumentation.

\begin{abstract}
In this study, it was investigate that the reflection of explicit-reflective nature of science (NOS) teaching and explicit-reflective argumentation based NOS teaching on prospective science teachers' written arguments about NOS. The reflection of different teaching methods about NOS on prospective science teachers' written arguments was assessed by using open-ended VNOS-C questionnaire (Lederman, AbdEl-Khalick, Bell, \& Schwartz, 2002). Sample of the study was composed of 70 prospective science teachers and two experiment groups. It was tried to bring NOS aspects to prospective science teachers, when first experiment group was enrolled in explicit-reflective argumentation based NOS teaching, other experimental group was participated in explicit-reflective NOS teaching during a semester. These experimental groups was decided to randomly assigned as first and second experimental groups from intact groups at department of science education in a public university. Prospective science teachers' views about NOS were evaluated by using VNOS-C as before and after implementation. Findings of the study showed that second experimental group participating explicit-reflective teaching about NOS had difficulties in constructing arguments before implementation but they showed development in constructing argument and constructing a low quality of scientific data and evidence after implementation. Another finding of the study showed that when explicitreflective argumentation based NOS teaching experimental group constructed low level of arguments before implementation, most of the participants constructed high level of arguments by using sound evidence and scientific data after implementation. Also, it was seen that a small number of prospective science teachers in this group used weak backing to questions about socially and culturally embedded NOS and creativity NOS aspects. As a result it was found that prospective science teachers get educated via argumentation based NOS teaching constructed more sound arguments about NOS than ones get educated via explicit-reflective based NOS teaching about NOS.
\end{abstract}

\section{Argümantasyon Temelli Açık Düşündürücü ve Açık Düşündürücü Bilimin Doğası Öğretiminin Öğretmen Adaylarının Yazılı Argümanlarına Yansıması}

\begin{tabular}{|c|c|}
\hline Makale Bilgisi & Öz \\
\hline DOI: 10.14812/cufej.309431 & $\begin{array}{l}\text { Bu çalışmada, açık düşündürücü bilimin doğası (ADBD) ve argümantasyon destekli açık } \\
\text { düşündürücü bilimin doğası (ADADBD) öğretiminin fen bilimleri öğretmen adaylarının }\end{array}$ \\
\hline & $\begin{array}{l}\text { bilimin doğasına ilişkin yazılı argümanlarının yapısına ve kavramsal anlamalarına } \\
\text { yansımaları incelenmiştir. Öğretmen adaylarının ADBD ve ADADBD öğretiminin bilimin } \\
\text { doğasına yönelik yazılı argümanlarının yapısına ve kavramsal anlamalarına yansımaları }\end{array}$ \\
\hline
\end{tabular}

*Author: emrah.higde@adu.edu.tr 


\begin{abstract}
açık uçlu VNOS-C (Lederman, Abd-El-Khalick, Bell, \& Schwartz, 2002) anketi ile değerlendirilmiştir. Çalışmanın katılımcıları 70 kişiden (iki deney grubundan) oluşmaktadır. Birinci gruba ADADBD etkinlikleriyle bilimin doğası özellikleri kazandırıırken, diğer gruba ADBD etkinlikleriyle bilimin doğası özellikleri bir dönem (3 ay) süresince kazandırılmaya çalışılmıştır. Bu gruplar bir devlet üniversitesinde var olan fen bilgisi eğitimi bölümündeki iki şubenin rastgele deney gruplarına atanmasıyla belirlenmiştir. Çalışmanın sonuçları ADBD uygulanan grubun uygulama öncesinde argüman kurmada zorlandıkları uygulama sonrasında ise zayıf kanıt ve veriler geliştirerek uygulama öncesine göre az da olsa bir gelişim gösterdikleri bulunmuştur. Çalışmanın bir diğer sonucu ise ADADBD uygulanan grubun uygulama öncesinde çok zayıf argümanlar oluşturduğu görülürken uygulama sonrasında çoğunluğun güçlü kanıt ve bilimsel veriler ile daha güçlü argümanlar kurduğu bulunmuştur. Ayrıca az sayıda da olsa bilimin, bilimsel bilginin sosyal ve kültürel değerlerden etkilenmesi ve hayal gücü ve yaratıcılığın bilimsel bilginin oluşmasındaki rolüne yönelik sorulara ilişkin zayıf destekleyicilerin ADADBD grubunda kullanıldığı görülmüştür. ADADBD uygulanan grubun, ADBD uygulanan gruba göre bilimin doğası özellikleri hakkında daha güçlü argümanlar kurduğu sonucuna ulaşılmıştır.
\end{abstract}

Anahtar Kelimeler:

Argümantasyon,

açık düşündürücü

bilimin doğası,

yazılı argümantasyon.

\section{Introduction}

Today, the changes in attitudes towards education cause significant changes in the aims of science education. It is clear that all of this information cannot be taught to all students when the rate of emergence of new scientific information is taken into consideration (Ministry of National Education [MONE], 2013). For this reason, in Turkey, as in many countries, the skills of reaching this information have been taken into the foreground of science literacy and science (Ministry of National Education [MONE], 2013), instead of transferring all the information in new education programs. One of the important sub-titles of scientific literacy, which is a top title that includes scientific concepts and skills, is the nature of science (Köseoğlu, Tümay \& Budak, 2008). In general, it refers to the values and beliefs inherent in the nature of science and epistemology of science, the development of science or scientific knowledge as a way of knowing (Lederman, 1992). McComas \& Olson (1998) concludes that science brings together various fields of science such as the nature of science, psychology, sociology, history of science and philosophy, and "what is science?, how do science work?, how do scientists work?, what is the influence of social and cultural contexts?" was addressed.

When the relevant studies in the literature in recent years about the nature of science are examined, it is seen that there is not a single definition accepted by all. However, when studies on the nature of science are examined, it can be said that the following general points best reflect the nature of science and the aspects of the nature of science;

- Scientific knowledge is being tested with experiments. So, scientific knowledge is factual. Observation and inferences are different from each other. Scientists also attach importance to how to justify the arguments of the evidence to make a claim using observation and data. In this process, scientists make inferences about observations and data, and therefore scientific knowledge is subject to change (McComas, 2004, Scwartz, Lederman \& Crawford, 2004; Lederman, 2007; Bell, 2009).

- Although the same data for a topic can be found in different inferences, different theoretical theories may arise. For this reason, when scientists decide which of these theories to support, they choose the theory that best fits the existing evidence, constantly question, develop and change knowledge. Therefore, scientific knowledge has a clear nature to change (Abd-ElKhalick, Bell \& Lederman, 1998, Khishfe \& Abd-El-Khalick, 2002, McComas, 2004, Scwartz, Lederman \& Crawford, 2004, 2009).

- Scientists are influenced by imagination and creativity while creating scientific knowledge (AbdEl-Khalick, Bell \& Lederman, 1998, Khishfe \& Abd-El-Khalick, 2002; McComas, 2004; Scwartz, Lederman \& Crawford, 2004; Bell, 2009). In addition, scientists are also influenced by the social 
and cultural values of the society in which the scientific knowledge, science, and knowledge are built (McComas, 2004, Scwartz, Lederman \& Crawford, 2004, Lederman, 2007; Bell, 2009).

In addition, Driver, Newton \& Osborne (2000) proposed the teaching of the nature of science in science education as a way to understand and follow the norms and ethical rules of the scientific community, to understand and follow sociological and scientific issues and processes which it is necessary for the content to be taught successfully. There are many different approaches to how nature of science is taught in science education as well as What is the nature of science in science education. When the literature is examined, approaches used in teaching nature of science; Historical, indirect and open-minded(Abd-El-Khalick \& Lederman, 2000, Khishfe \& Abd-El-Khalick, 2002). However, in recent years, it has been seen that teaching with argumentation-oriented and argumentationoriented teaching, together with scientific argumentation focused on explicit-reflective approach, is the subject of research in teaching (Çetin, 2014, Demircioglu \& Uçar, 2014). In the science curriculum of elementary education institutions, the basic approach is the argumentation that the teacher, who is actively involved in the planning and implementation of the lessons, assumes more guidance role. It is therefore expected that teachers should create an environment in which students can freely express their thoughts, defend these thoughts for different reasons, and create counter arguments in order to refute opposing views. It is also expected that teachers will take the role of guiding and guiding the students to support the claims they have made and their counterclaims with reasonable justification. As a result, the importance of argumentation based teaching emerges in science education.

\section{Science teaching with explicit-reflective scientific argumentation}

Common misconception about scientific argumentation was that scientific argumentation was seen as simple discussion and claims. Actually, argumentation could be defined as configuration process of suitable warrants which associated with the data they are based on claims (Toulmin, 2003). Actually, there is no only one definition about argumentation but also according to Toulmin (2003), argumentation was defined as claim and accompanying justifications. Jimenez-Aleixandre and Erduran (2007) have identified argumentation two ways in terms of individual and social. From the individual perspective, argumentation was thought as any claim was justified by person, any opinion about this claim was formed by person or argumentation process of person. From the social perspective, argumentation was defined as discussion and rebuttal of opposite opinions about same topic. Studies about argumentation practices in science education showed some limitations related with poor argumentation skills, disregarding to data and warrant, lack of inferences and comments about claim sufficiently, achieving results by not using warrant and data and limitations about assessing of opposite opinions (Driver, Newton, \& Osborne, 2000). Studies about classroom practices of argumentation showed that classroom was suitable for teacher-centered education and there was no necessary discussion atmosphere for argumentation to incorporate students in argumentation process (Newton, Driver, \& Osborne, 1999). Argumentation based classroom practices in science education has been shifted explicit-reflective argumentation education in time (Cetin, 2014, Khishfe, 2014; Zohar \& Nemet, 2002). Inexplicit-reflective strategy, argumentation was introduced explicitly and taught students in terms of structural, functional and application based on assessment criterions (McDonald, 2010). In studies, implemented in scientific context and with explicit argumentation, development of argumentation skills and quality of arguments was realized (Bell \& Linn, 2000; McDonald, 2008; Yerrick, 2000; Zohar \& Nemet, 2002). For this reason, it can be said that explicit argumentation and scientific context used in studies were effective to improve quality of arguments and students argumentation skills. Also, considering history of science, scientists assert different theories by using and looking at same data. In addition, when scientists decide which theories can be supported, they pay attention to which one is consistent with existed evidences. Similarly, it was expected from students that they can improve own claim which was consistent with existing evidences, include rebuttals of opposite claims and high quality of justifications instead of asserting claims and conclusions (Driver et al., 2000). Scientific argumentations can be seen as process of students reveal scientific claims about science topic, 
support, criticize, assess and revision and correction of asserted claim. At the end of this process, students can see science as a process including proposed claims continuously, questioning of these claims and generally developments and changing of these claims (Cetin 2014; Khishfe, 2012). Evolving, changing and inquiry aspects of science can be seen as combining characteristics of nature of science and scientific argumentation. In addition, some studies (Jimenez-Aleixandre \&Erduran, 2007; McDonald, 2008; McDonald \& McRobbie, 2011; Khishfe, 2014) investigated the combinations of nature of science and scientific argumentations and results supported nature of science education with argumentation.

Recently, argumentations based studies in the context of nature of science showed that argumentation based explicit-reflective teaching was effective to improve students' views towards nature of science and quality of argumentations (Cetin 2014; Khishfe, 2012, 2014; McDonald, 2008; McDonald \& McRobbie, 2011). Considering literature review about nature of science and argumentation studies was collected together under two headings. Studies in the first heading investigated how students' views about nature of science influence on quality of their arguments and problems of students in forming argumentation (Bell \& Lederman, 2003; Sadler, Chambers, \& Zeidler, 2004; Walker \& Zeidler, 2004). Studies in the second headings researched on how argumentation teaching reflect on and influence on students' views about nature of science (Bell \& Linn, 2000; Yerrick, 2000; Ogunniyi, 2006). In addition to these studies, argumentation can be seen as mechanism to learn scientific epistemology (Sandoval \& Millwood, 2007). One of the objectives of argumentation in the context of science education is the development of the ability of use evidence and backings to support their claims about a scientific topic (Kelly, Regev, \& Prothero, 2008; McDonald, 2008; Sandoval \& Millwood, 2007; Yore, Florence, Pearson, \& Weaver, 2006). The results of studies about oral argumentation showed that students in cooperative learning or problem solving education generally make claims without using backings and evidences in group works (Erduran, Simon \& Osborne, 2004; Jimenez-Aleixandre, Rodriguez, \&Duschl, 2000; Kelly et al., 2008). It was seen that studies about written argumentation also provide opportunity to investigate students' argumentation structure, to decide students' thinking schema about claims, to evaluate the others studies (Bell \& Linn, 2000; Kelly et al., 2008; Sandoval, 2003). If students were wanted to educate as scientifically literate person or scientists, it was needed that students should have improved nature of science opinions, creativeness, and sophisticated argumentation skills. For this reason, the most important mission in the training of these individuals falls to teachers and the education institutions that will train these teachers.

To comprehend above mentioned new teaching approach related with nature of science, one of the best effective teaching approaches is to engage students in explicit-reflective argumentation based science education process. In this context, the aim of this study was to investigate that the reflection of explicit-reflective nature of science (NOS) teaching and explicit-reflective argumentation based NOS teaching on prospective science teachers' written arguments about NOS.

\section{Method}

\section{Research Design}

In this study, pretest-posttest without control group experimental design was used to determine the quality of prospective science teachers' their written arguments about the nature of science. In this research model, cause-and-effect relationship between variables is determined (Campbell \& Stanley, 1963). When explicit reflective argumentation based nature of science education was implemented in first experimental group, explicit reflective nature of science education was implemented in second experimental group. Qualitative techniques were used to collect data. By using VNOS-C scale, students' written arguments about nature of science view was collected and descriptive analysis was used.

\section{Participants}

Sample of the study was composed of 70 (52 female, 18 male) prospective science teachers and two 
experiment groups. These prospective science teachers were $3^{\text {rd }}$ grade level students and firstly they attended "nature of science and history of science" course during their undergraduate education. Participants were divided into 30 prospective science teachers (26 female and 4 male) in first experimental group and 40 prospective science teachers ( 26 female and 14 male). Classrooms were randomly assigned into first and second experimental groups. First experimental group were attending explicit-reflective argumentation based NOS teaching. Second experimental group were attending explicit-reflective nature of science (NOS) teaching. Reflection of implemented teachings in experimental groups to structure of prospective science teachers' written arguments and conceptual understandings of them was determined as comparing before and after practice.

\section{Data Collection}

Views of Nature of Science Questionnaire (VNOS) was developed by Lederman and colleagues (2002), translated and adapted in Turkish by Küçük (2006), was used to determine prospective science teachers' views of nature of science at the beginning and ending of spring semester in 2013-2014 year. The View of Nature of Science Questionnaire (VNOS-C) was composed of 10 open-ended questions about aspects of nature of science. Questionnaire was implemented as pretest and posttest before and after practice. The scale was aimed to find out students' views about aspects of nature of science such as empirically based, differences between observation and inference, differences between theory and laws, creativity, subjectivity or theory-laden, culturally and socially embedded, tentative. Example question from questionnaire was "Is there a difference between a scientific theory and a scientific law? Illustrate your answer with an example."

\section{Procedure and Administration}

In nature of science and history of science course, explicit-reflective argumentation based NOS teaching and explicit-reflective nature of science (NOS) teaching based on seven aspects of nature of science activities were prepared for experimental implementations. Also, history of science activities was implemented in this course. In addition, the historical development of science for prospective teachers were processed as Egypt-Mesopotamia, Ancient Greek, Medieval, Science in Islam, Renaissance, Science in the 17-18th century, Science in the 19-20th century and science periods in Turks. Each week, the discussion activities focused on the philosophical features of the period and the developments that were being processed.

Prepared activities were aimed to bring prospective science teachers aspects of nature of science and argumentation skills. All activities include group works and beginning with prospective science teachers' questions and presentations about nature of science. Activities were designed to explicitly present seven aspects of nature of science and actively explain and discuss participants' ideas about nature of science and history of science. The Great Fossil Find and tricky tracks activities were used from literature (Lederman \& Abd-El-Khalick, 1998; Doğan, Çakıroğlu, Bilica \& Çavuş, 2012). Discussions of content and science process skills were based on reflective nature of science teaching. After each activity, nature of science aspects were especially paid attention and reflection opportunity about relations about nature of science aspects were given to students under guidance of instructor. These activities based on seven aspects ofnature of science;

- Scientific knowledge is tentative (subject to change).

- Science is empirically based (based on or derived from observation of the natural world).

- Science is inferential, imaginative and creative.

- Science is subjective and theory laden.

- Science is socially and culturally embedded.

- The distinction between observation and inferences.

- The relationships between scientific theories and data. 
Main concepts and other concepts related with nature of science aspects focused in activities also were explained. Subject, content and implementation of activities were presented below.

\section{Explicit-reflective argumentation based NOS teaching activities in first experimental group}

Following activities only were presented in first experimental group via explicit-reflective argumentation based NOS teaching. During implementation period, only one activity was presented for each week.

\section{Activity: Does the scientific knowledge change?}

In this activity, it is aimed to give students the opportunity to experience the changes of scientific knowledge by making claims about whether the prospective teachers have changed their scientific knowledge. Two proposals were given to the prospective teachers (scientific knowledge changed and scientific knowledge did not change) and they were asked to give evidence and to reason with which they participated and why they supported it. Then, it is desirable to refute the claims against their own views. At the end of the activity, it was aimed that the prospective science teacher would learn the claim of "scientific knowledge is change" through an explicit-reflective argumentation approach.

2. Activity: is scientific knowledge subjective?

In this activity, it is aimed that prospective science teacher should experience why scientific knowledge is subjective by making claims about whether or not scientific knowledge is subjective. In the activity, it is desirable that prospective science teachers were given two arguments (scientific knowledge is subjective and scientific knowledge is not subjective) and they are asked to present evidence and reasoning which one they are agreeing and why they support it. Later, they were asked to give refutations against the claims of opposition. At the end of the activity, it was aimed that prospective science teachers would learn the argument that scientific knowledge is subjective through explicitreflective argumentative approach.

\section{Activity: Will there be a big earthquake in Istanbul?}

In this activity, it is aimed that prospective science teachers should experience scientific knowledge and knowledge about whether scientific knowledge is subjective and whether scientific knowledge can be affected from the social and cultural environment. In order to understand whether scientific knowledge is subjective, two readings were given to prospective teachers. These readings were describing the reports of two different professors who claim to have an earthquake or not until 2015 in Istanbul. One of the readings claimed that a major earthquake would be realized until 2015 in Istanbul with scientific evidences, while another reading claimed that there is no evidence that there would be an earthquake in Istanbul until 2015. As a result of these readings, it is aimed to apply the explicitreflective argumentation based nature of science teaching approach so that prospective science teachers learn that scientific knowledge can be affected from the social and cultural environment and scientific knowledge is subjective.

\section{Activity: Do we need evidence from experiments and observations for scientific knowledge?}

In this activity, it was aimed that prospective science teachers should make a claim about whether or not scientific knowledge is based on experiments and observations, so that they should experience why scientific knowledge needs evidence from experiments and observations. In this activity, two proposals were given prospective science teachers (evidence from experiments and observations is needed for scientific knowledge and evidence from experiments and observations is not required for scientific knowledge) by asking them which one they participated in and why they supported it, and they were asked to provide evidence and to reason. Then, they were asked to present rebuttal against their opposing views.At the end of the activity, it was aimed that the prospective science teachers would learn the claim that scientific knowledge is based on experimentation and observation, with an explicit- 
reflective argumentation based nature of science teaching approach.

\section{Activity: Tricky Tracks}

This activity aims to inform prospective science teachers about differences between observation and inference in a scientific research and the uncertain aspects of nature of science.In the first part of the activity, it was attempted to give the prospective science teachers the message that "all the different opinions about a subject are not representative of the correct answer". In this activity, different shapes were projected onto the screen with the help of the projector and asked students to explain what they might have been in each case. Firstly prospective science teachers wrote explanations on worksheet, and then they were encouraged to share their explanations with the class. Focusing on the scenarios of the students about these pictures, they were taught the concept of difference between observation and inference. Again, it is reasonable to have different inferences about the same data (picture) but it is emphasized that these inferences cannot be fully explained the data (picture). At the end of this activity, it has been stated that many inferences can be made at the same level on the same question based on the same data. It is stated that while scientists are trying to find answers to the questions about natural phenomena, they make similar inferences. Scientists have been argued that a single answer cannot explain it alone, even though the given answers to the questions are consistent with existed data. Throughout the event, it is desirable that prospective science teachers present their own assertive evidence for their own claims and present their counter-arguments and qualifiers. At the end of the activity, it was aimed that prospective science teachers understand difference between observation and inference by the explicit-reflective argumentation based nature of science teaching approach.

\section{Activity: Fossils}

This activity is aimed that prospective science teachers recognize the importance of imagination and creativity in a scientific research. In the first part of the activity, prospective science teachers were given a picture of a fossil piece so that they could figure out what kind of creature it might belong to and draw it. Then, prospective science teachers are asked to present qualifiers and rebuttals that defend their own beliefs. At the end of this activity, the prospective science teachers are presented with a picture of fossil belongs to which organism.

Prospective science teachers are guided through the discussion of why different creatures' pictures were plotted and are able to realize that different results can be reached from the same data while generating scientific knowledge. Prospective science teachers completed fossil piece by using their own imagination and they were asked to argue whether scientists are using their imagination and creativity while creating scientific knowledge like themselves or not. At the end of the activity, it was aimed that prospective science teachers understood that scientists were influenced by the imagination and creativity in the creating of scientific knowledge.

\section{Activity: Relationship Between Law and Theory}

This activity aims that prospective science teachers comprehend the differences between theory and law in a scientific research. Prospective science teachers are given two theories and a list of evidence supporting any of these two theories at the beginning of the activity (Theory 1-Theories turn into laws when they are adequately supported by new evidence, and Theory 2-Laws and theories represent different scientific knowledge and there is no hierarchical order between them). Prospective science teachers were asked to discuss the theories using these evidences. Prospective science teachers either accepted or rejected the theories using the evidence. As a result of this activity, it is aimed that prospective science teachers will understand the relation between theory and law. In the course of this activity, it was emphasized that students could be given a reading that explains the historical change of a changing physics law and that scientific laws may change in the light of the new data. 


\section{Explicit-reflective NOS teaching activities in second experimental group}

In the following activities using in this experimental group, explicit-reflective NOS teaching approach was used.

\section{Activity: Spontaneous Formation Theory}

In this activity, the experiments of Louis Pasteur and previous experiments in a historical order were given to prospective science teachers with explicit-reflective teaching approach to grasp how scientific knowledge changed in the course of time. Then, it was asked prospective science teachers to give a similar example by asking whether the scientists change experiments and other theories over time. Louis Pasteur proved that in the experiments, there was no spontaneous formation of living things in the environment with water and adequate nutrients. Because the experiments carried out in the early years, it is argued that the frogs pass to the soil by rain water. Louis Pasteur has refuted this theory with his experiments. As a result of this activity, it was aimed that prospective science teachers comprehended how scientific theories could change in the light of new knowledge and experiments.

\section{Activity: Is it scientific or not?}

In this activity, prospective teachers are requested to give scientific and non-scientific expressions to determine whether they are scientific and to explain the reasons. In this way, it is ensured that the prospective teachers can decide about the characteristics of scientific knowledge by arguing. The conclusion of this activity is that science uses experiments, logical debates and doubts to distinguish itself from other research fields and information.

\section{Activity: Teaching the Nature of Science Using Newspaper News}

In this activity, prospective science teachers were given a reading that explains the discovery of the scientists who produce water-free and dirty-free surface coating material by observing and experimenting with the lotus flower that was published in the National Geographic News magazine. Through this activity, it was tried to be understood that the science was based on experiments. As a result of this activity, it was aimed that prospective science teachers should understand that scientific knowledge based on experiments, logical discussions and observations in nature.

4. Activity: Science with roundhouse diagram

In this activity, prospective science teachers are given a roundhouse diagram, asking what the science is and demanding them to fill in the roundhouse diagram. Everybody's definition is different because they will fill the roundhouse diagram themselves. Each prospective science teacher conceptualize that scientific knowledge is subjective and properties of scientific knowledge by filling roundhouse diagram because they fill title of roundhouse diagram and properties of scientific knowledge in the roundhouse diagram. As a result of this activity, it was aimed that prospective science teachers conceptualize the characteristics of scientific knowledge.

\section{Activity: New fossils}

This activity is aimed that prospective science teachers recognize the importance of imagination and creativity in a scientific research. In this activity, prospective science teachers were given a reading about the new fossil of the eye. Different interpretations have been made about which organism fossil of the eye belongs to. Scientists have decided which organism fossil of eye belongs to using their own imagination and creativity. As a result of this activity, it was aimed that prospective science teachers conceptualize the influence of imagination and creativity in the formation of scientific knowledge.

\section{Data Analysis}

Answers of prospective science teachers about nature of science questionnaire were read and investigate by two experts for science education and nature of science to improve validity and reliability 
of the study and categorized into "none", "weak", "strong" categories. Categories of the experts were found to be coherent among categories of experts. As a result of the analysis made, consistency among experts was found to be $75 \%$. If answers of prospective science teachers include accurate and sufficient claim, data, warrant and rebuttal components, it was categorized as strong, if accurate but not enough, it was categorized as weak, if not accurate and not enough or not answered, it was categorized as none (Table 1). Also, "Argumentation Levels" (Osborne, Erduran, \& Simon, 2004) and other studies (Driver et al., 2000; Zohar \& Nemet, 2002) got referenced and it has been taken into account consistency with Turkish argumentation model (Aktamış \& Hiğde, 2015), conceptual understanding and whether reasoning was used or not (Sampson \& Clark, 2008) to assess the quality of argumentation. According to these evaluation criteria, the frequency distributions according to the argument components of the categorized answers are given in Table 2. In order to demonstrate the change in the written arguments that teacher candidates use to express their views on the nature of science, frequency distributions of pre- and post-implementations are given separately. While the frequency distributions in Table 2 and Table 4 constituted the quantitative part of the study, quotations supporting this frequency distribution composed the qualitative part of. Supportive findings were included through qualitative and quantitative findings.

Table 1.

Evaluation criteria

\begin{tabular}{|c|c|c|c|c|}
\hline \multicolumn{2}{|l|}{ Components } & 0 (none) & 1 (weak) & 2 (strong) \\
\hline \multicolumn{2}{|c|}{$\begin{array}{l}\text { Claim } \\
\text { A claim and result answers original } \\
\text { question }\end{array}$} & $\begin{array}{l}\text { None claim or } \\
\text { uncertain claim }\end{array}$ & $\begin{array}{l}\text { Certain but } \\
\text { incomplete } \\
\text { claim }\end{array}$ & $\begin{array}{l}\text { Certain and complete } \\
\text { claim }\end{array}$ \\
\hline \multirow[t]{2}{*}{$\begin{array}{l}\text { Evidence scientific } \\
\text { data supports } \\
\text { claim. Data was } \\
\text { suitable and } \\
\text { enough to support } \\
\text { claim. }\end{array}$} & $\begin{array}{l}\text { a. data } \\
\text { data supports the } \\
\text { claim }\end{array}$ & Wrong or none & $\begin{array}{l}\text { Data from } \\
\text { experience in } \\
\text { everyday life }\end{array}$ & $\begin{array}{l}\text { Give data by } \\
\text { comparison with } \\
\text { others. Utilizing } \\
\text { experimental and } \\
\text { scientific data. }\end{array}$ \\
\hline & $\begin{array}{l}\text { b. reasoning } \\
\text { the statement } \\
\text { connect data and } \\
\text { claim each other }\end{array}$ & Wrong or none & $\begin{array}{l}\text { Insufficient } \\
\text { reasoning }\end{array}$ & $\begin{array}{l}\text { Sufficient reasoning } \\
\text { supported by scientific } \\
\text { data }\end{array}$ \\
\hline \multicolumn{2}{|c|}{$\begin{array}{l}\text { Warrant } \\
\text { Conceptual quality of warrant }\end{array}$} & $\begin{array}{l}\text { None warrant- } \\
\text { wrong or none }\end{array}$ & A warrant & $\begin{array}{l}\text { More than one } \\
\text { warrant }\end{array}$ \\
\hline \multicolumn{2}{|c|}{$\begin{array}{l}\text { rebuttals } \\
\text { explanations and claims to opponents } \\
\text { claims }\end{array}$} & $\begin{array}{l}\text { None rebuttals- } \\
\text { wrong or none }\end{array}$ & A rebuttals & $\begin{array}{l}\text { More than one } \\
\text { rebuttal }\end{array}$ \\
\hline
\end{tabular}

\section{Findings}

The frequency distributions of the answers to the VNOS-C questionnaire by students in the explicitreflective argumentation based nature of science teaching implemented experimental group and explicit-reflective nature of science teaching implemented experimental group before and after the science courses. The frequency distributions of the explicit-reflective argumentation based nature of science teaching implemented experimental group are given in Table 2, while the distributions of the explicit-reflective nature of science teaching implemented experimental group are given in Table 4. 


\section{a) Results of the explicit-reflective argumentation based nature of science teaching experimental group}

The frequency distributions of the participants' responses to the VNOS-C questionnaire before and after the nature and history of science lessons supported by explicit-reflective argumentation based activities were given below (Table 2). The second question on the VNOS-C questionnaire, "What is an experiment?" is not included in analyses. Because this question is a question of information, it is not a suitable question for students to make arguments and to reason.

Table 2.

Frequency distribution of prospective science teachers' VNOS-C results pre and post explicit-reflective argumentation based NOS teaching implementation

\begin{tabular}{|c|c|c|c|c|c|c|c|c|c|c|c|}
\hline Components & Timing & & 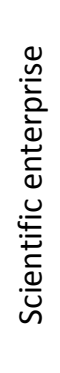 & 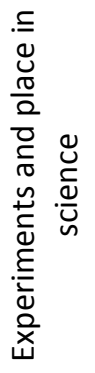 & 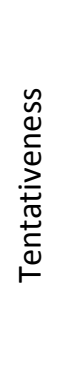 & 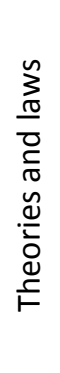 & 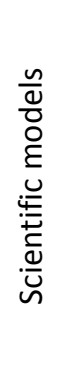 & 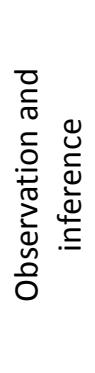 & 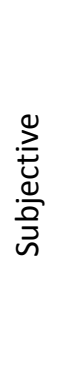 & 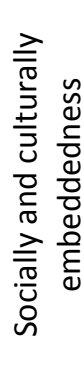 & 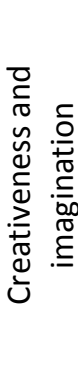 \\
\hline \multirow{6}{*}{ Claim } & \multirow{3}{*}{ Pre-implementation } & None & 17 & 5 & 2 & 7 & 6 & 8 & 17 & 8 & 4 \\
\hline & & Weak & 9 & 17 & 17 & 18 & 21 & 16 & 12 & 17 & 18 \\
\hline & & Strong & 4 & 8 & 11 & 5 & 3 & 6 & 1 & 5 & 8 \\
\hline & \multirow{3}{*}{ Post-implementation } & None & 6 & 1 & 2 & 0 & 5 & 4 & 0 & 1 & 0 \\
\hline & & Weak & 5 & 3 & 4 & 11 & 9 & 12 & 10 & 3 & 6 \\
\hline & & Strong & 19 & 26 & 24 & 19 & 16 & 14 & 20 & 26 & 24 \\
\hline \multirow{6}{*}{ Reasoning } & \multirow{3}{*}{ Pre-implementation } & None & 24 & 16 & 10 & 19 & 20 & 16 & 25 & 14 & 18 \\
\hline & & Weak & 6 & 10 & 19 & 10 & 8 & 14 & 4 & 16 & 12 \\
\hline & & Strong & 0 & 4 & 1 & 1 & 2 & 0 & 1 & 0 & 0 \\
\hline & \multirow{3}{*}{ Post-implementation } & None & 7 & 1 & 3 & 5 & 7 & 7 & 6 & 2 & 5 \\
\hline & & Weak & 9 & 8 & 10 & 10 & 8 & 10 & 8 & 6 & 6 \\
\hline & & Strong & 14 & 21 & 17 & 15 & 15 & 13 & 16 & 22 & 19 \\
\hline \multirow{6}{*}{ Data } & \multirow{3}{*}{ Pre-implementation } & None & 27 & 22 & 15 & 19 & 17 & 18 & 26 & 17 & 22 \\
\hline & & Weak & 3 & 4 & 13 & 10 & 11 & 12 & 3 & 13 & 7 \\
\hline & & Strong & 0 & 4 & 2 & 1 & 2 & 0 & 1 & 0 & 1 \\
\hline & \multirow{3}{*}{ Post-implementation } & None & 16 & 9 & 12 & 12 & 12 & 7 & 13 & 5 & 7 \\
\hline & & Weak & 6 & 7 & 11 & 7 & 5 & 13 & 9 & 8 & 7 \\
\hline & & Strong & 8 & 14 & 7 & 11 & 13 & 10 & 8 & 17 & 16 \\
\hline \multirow{6}{*}{ Warrants } & \multirow{3}{*}{ Pre-implementation } & None & 30 & 29 & 30 & 30 & 28 & 30 & 30 & 29 & 29 \\
\hline & & Weak & 0 & 0 & 0 & 0 & 2 & 0 & 0 & 1 & 0 \\
\hline & & Strong & 0 & 1 & 0 & 0 & 0 & 0 & 0 & 0 & 1 \\
\hline & \multirow{3}{*}{ Post-implementation } & None & 30 & 24 & 26 & 25 & 24 & 26 & 27 & 20 & 25 \\
\hline & & Weak & 0 & 0 & 1 & 1 & 2 & 2 & 1 & 4 & 1 \\
\hline & & Strong & 0 & 6 & 3 & 4 & 4 & 2 & 2 & 6 & 4 \\
\hline \multirow{3}{*}{ Rebuttals } & \multirow{3}{*}{ Pre-implementation } & None & 30 & 30 & 30 & 30 & 30 & 30 & 30 & 30 & 30 \\
\hline & & Weak & 0 & 0 & 0 & 0 & 0 & 0 & 0 & 0 & 0 \\
\hline & & Strong & 0 & 0 & 0 & 0 & 0 & 0 & 0 & 0 & 0 \\
\hline
\end{tabular}


Emrah HiĞDE, Hilal AKTAMIŞ - Çukurova Üniversitesi Eğitim Fakültesi Dergisi, 46(1), 2017, 39-84

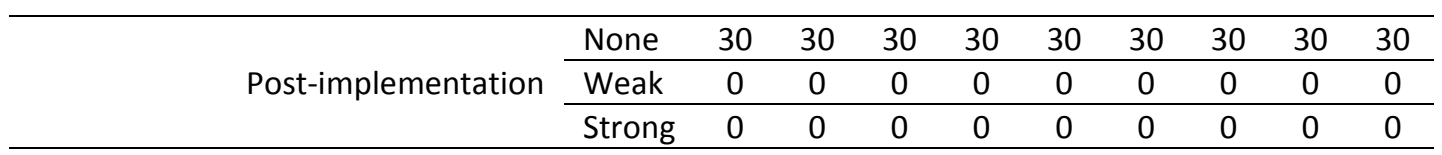

When Table 2 is examined, it can be seen that most of the prospective teachers are able to make weak arguments before application, but they can establish strong arguments after the application. When the reasoning component is taken into consideration, it has been determined that the majority of the prospective teachers failed in reasoning, but more than half of the participants were able to provide strong reasoning after the application. It has been determined that more than half of the participants are able to provide more powerful data than participants who are not able to show much improvement compared to the preliminary data, but who are influenced by the social and cultural values of scientific knowledge and the role of imagination and creativity in the formation of scientific knowledge. Taking into account the reasoning and data components, it is seen that the majority of the prospective teachers failed in evidence but more than half of the participants were able to provide strong evidence after the implementation. Very few of the prospective teachers have been found to be in a supportive position. Participants were found to have never improved in the refutation step. In order to support these frequency data, the following are cited for each questionnaire and they are given under separate titles before and after the application.

Table 3 gives a summary of the answers given by prospective teachers regarding the questionnaire of the nature of science applied before and after argumentation based explicit-reflective nature of science education. In the preliminary application, participants gave answers such as science being based on more experiments, questionable, objective, and prone to reason and conjecture. The majority of participants think that experiments are needed to develop science. They have supported these claims with the need for experiments for the observability, verifiability, experimentability, development and change of science. A large part of the participants thought that scientific theories will change over time. They have supported these claims by the fact that scientific knowledge can be refuted by the developments. If it were certain, it was found that there were misconceptions about the transition to the law. The vast majority of prospective teachers state that there is a difference between theory and law. At the same time, it has been seen that the vast majority of prospective teachers have the conceptual misconception that scientific theories will eventually turn into laws. Participants were convinced that theories for which theories are not definitive are precise information, so theories that the laws cannot refute will eventually be refuted. Teacher candidates questioned how scientists use specific information about the atom and how confident they are about the structure of the atom, by means of the experiments and the advanced tools used, and by the theories developed over a long period of time, they have been able to assure themselves of atomic structure. Teacher candidates have tried to support how scientists are confident about a species by showing examples of external appearance, genes, chromosome numbers, progeny, and experimentation in peas. Teacher candidates often fail to answer the question of how scientists reach different outcomes by looking at the same results and the same data, or they have stated that the event may have multiple causes. The majority of prospective teachers claim that science is universal about whether science is universal. Very few prospective teachers have claimed that science can be influenced by personal values and the values of society. Teacher candidates express the fact that imagination and creativity play an active role in science. They claimed that imagination and creativity played an active role in almost every phase.

Teacher candidates claimed that in their post-application answers, science is different from other fields of research, that science is more objective, provable, and tested with scientific process skills than verbal fields such as religion and philosophy. Teacher candidates expressed the need for experimentation for the development, validation and realization of science. The vast majority have also tried to support the importance of experimenting with the formation of scientific knowledge by giving examples from scientific experiments and inventions. Teacher candidates have been arguing that scientific theories may change over time. In addition, according to the preliminary application, it has 
been found that the teacher candidates mostly try to give evidence, data and supporting examples and examples from the scientific history and scientific theories they have encountered in practice. Teacher candidates state that the difference between scientific law and theory is that there is still a hierarchical relationship between them and that the law cannot be changed. However, according to the answers before implementation, they tried to support their claims with scientific theories, laws and examples from the history of science, even though their claims in post-implementation answers are wrong. Teacher candidates have long argued thedifferent perspectives, many experimental results, technological advances and new experiments, in short, the knowledge of atomic structure, can be assured by the accumulation of scientific knowledge. Prior to application, the teacher candidates used scientific theories and development to further support their claims and provide evidence. Teacher candidates have stated that scientists are observing species when researching species, using features similar to species, and being able to make certain of the inferences and species based on them. They also said that they considered the ability of the species to yield fertile fertilizers when they mated. Prior to the application, it was found that the prospective teachers tried to support their claims by giving more scientific examples and knowledge and tried to provide evidence. Teacher candidates have tried to explain how scientists reach different results using the same data, with scientists having their own individual views and assumptions. They have tried to support these claims by using different scientific theories. The majority of prospective teachers stated that scientific knowledge is objective, that science is influenced by social and cultural values, and by the philosophical and religious values and economic conditions of the society it is in. Prior to the application, it was seen that the participants had changed both in their views and tried to provide evidence and evidence by giving examples and theories from the history of science. They claim that science is based on imagination and creativity. Prior to the application, the teacher candidates pointed out the importance of creating more scientific knowledge of imagination and creativity with stronger claims. They tried to support and prove their claims by exemplifying the discoveries and inventions of scientists such as Newton, Archimedes, Einstein, Mendel and Thomson. In Table 3 below, the pre- and post-implementation views of students whose answers are conspicuous and understandable are given.

\section{Table 3.}

Quotations of teacher candidates' opinions Pre- and Post-implementations in argumentation based explicit-reflective nature of science teaching group

\section{Opinions before implementation}

ÖP: "Science examines the nature and nature of nature. It also explains the situations that cause this behavior. (Law, theory, etc.), it is in the framework of cause-and-effect when making explanations of different situations from other research fields, and if there is a lawful case, it is explained by experiments, with evidence."

ÖZ: "The science means knowing nature, universe and environment. What makes science different from other fields is experimentally provable."

ÖU: "After science has existed, it examines the events that occur in nature. It is the object. It depends on reason and judgment. Religion and philosophy examine the cause of existence. He is subjective."

\section{Opinions after implementation}

ÖA: "Scientific nature is a field of interest that creates definitions of living things, lifeless assets, and concepts that explore the living environment. Verbal fields such as religion and philosophy are more subjective than object. It can vary depending on the experience of the person's ideas and his past experience. Areas such as physics, chemistry and biology are tested with scientific process skills. They pass to the objective dimension."

ÖS: "The science means the process of reaching a wisdom or discovery as a result of the curiosity of the scientist with the observations, the experiments, the discoveries. The feature that distinguishes science from other research areas is that it can be tried and proved. It is desired to reach certain knowledge in the frame of certain reason and logic." 
ÖZ: "Yeah. Because scientific knowledge must be observable or provable. Experiments are needed because experiments made reveal different information. Smooth surface makes movement difficult."

ÖB: "Yes there is. For example, the information given in the first atomic model is insufficient and more advanced results have emerged in the direction of scientists' researches."

ÖG: "Yes there is. The experiment proves the information. True and false information are separated in this way. In this way scientific knowledge develops."

ÖD: "Yes, experiments are needed. Scientific knowledge is knowledge that is supported and this is often through experimentation. For example, atomic theory is the scientific knowledge obtained from experiments and observations."

ÖN: "Is necessary. The best way to have knowledge is to try and observe. For example, students want to learn how to lift water. We can show them by putting some water into the cabinet with the simplest arrangement and leaving a few light objects on it."

ÖG: "Yes, a scientific theory can change over time. Because the theory can be refuted after a long period of time over the theory that was created according to the conditions of that time."

ÖM: "Because the theory does not become a direct law when we find many experiments are done through the theories. Finally, the theory, which is the right theory, becomes legal. Therefore, different theories can be written constantly, the theories can be changed."

ÖGA: "Yes, it may change. For example, when we y look at atomic models, it begins with Dalton. Until Bohr, the errors are noticed and changed. The theories were never looked at. There must be a law to not change. Theories may change."

ÖA: "Theories may change. The laws do not change. Although the Newtonian laws of motion are everywhere the same, the theory of evolution is not accepted. It provides contributions to them by examining the regulation of theories. A scientist presents a new theory that deals with a previous theory and fixes its deficiencies."

ÖMA: "It may change. Because, in the atomic theories, every scientist has been influenced by each other from the very beginning and has disproved their theories. While there was no concept of orbit in the first atomic theory, other scientists found orbit. We need to learn theories. Because the next theories are formed from the first theories."
ÖP: "Yes there is. Because experiments are scientific steps that are made to confirm the observations made. The scientific process is the third step to experiment. For example, if Faraday did not experiment, he could not reach the laws that show the relationship between the magnetic field and electricity."

ÖZ: "We can exemplify many things we use in our everyday life. Pendulum clocks, car wheels, acid and base reactions. We can learn all of this by applying scientific knowledge to experiments."

ÖH: "Yes, because there is a need for experimentation to be able to research a claim with evidence and supporters. It is easier to prove and defend scientific knowledge made with experiments. For example, Newton's experiments with gravity."

ÖBA: "Yes there is. Scientific knowledge evolves by doing experiments. For example, the lifting force of fluids has evolved through experiments. Newton's gravity law is an example. Evidence of scientific knowledge can be defended by conducting experiments."

ÖM: "Yeah. Because scientific evidence requires evidence to prove it. As an example, gravity force, experiment and observation, Newton's head falls into apples."

ÖM: "Scientific theories may change. Theories can be affected from time to time. For example, even the culture structure of that period is influential. The toolrestraint theories that can be used indicate that theories may change. For example, the atomic theories Dalton-Thomson-Rutherford atom theories evolved over time. Because the tools they use are influential. Science progresses cumulatively. Each theory has set the ground for the other. Theories also bring a sense of curiosity."

ÖBB: "Scientific theories change. Atomic theory and the theory of evolution add new information on the progress of science and the development of technology. As time progresses, new evidence emerges. So scientific theories can change."

ÖH: "Theories are changing. For example, new ideas emerge every day into the atom and the theory of evolution, changing the theories. The current theory of evolution is a clear theory. It has opened to the new investigations because the theory is openended.In these new researches, theory is changing by joining theory." 


\begin{tabular}{|c|c|}
\hline 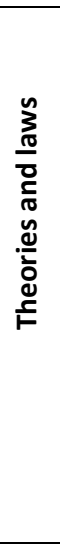 & $\begin{array}{l}\text { ÖS: "It certainly exists. Scientific theory can be } \\
\text { proved by experiment or it may be wrong. But the } \\
\text { law certainly does not change. Darwin's theory is } \\
\text { not certain." } \\
\text { ÖU: "There is a difference. Although the theory is } \\
\text { changeable, the law cannot be changed. For } \\
\text { instance, despite the emergence of different } \\
\text { thoughts despite the theory of evolution, no such } \\
\text { contrary ideas have been put forward in Newton's } \\
\text { time. It was just supportive. It is accepted and } \\
\text { final." } \\
\text { ÖB: "A scientific theory can be refuted, but the law } \\
\text { cannot be refuted. The Ohm law and the theory of } \\
\text { evolution are examples." }\end{array}$ \\
\hline 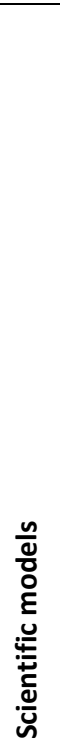 & $\begin{array}{l}\text { ÖBA: "After they have done so many experiments, } \\
\text { they come to such a judgment. After researching } \\
\text { with advanced instruments, they reveal this } \\
\text { information." } \\
\text { ÖD: "The discovery of atoms and particles by } \\
\text { scientists has not been rapid. This can be } \\
\text { understood from the various atom models (Bohr, } \\
\text { Dalton, Thomson) as well as the gradual trial-and- } \\
\text { error method. For example, the Millikan } \\
\text { experiment has shown us that electrons have also a } \\
\text { mass. Each subsequent scientist has produced new } \\
\text { theories in light of this information, paying } \\
\text { attention to this information." } \\
\text { ÖA: "The data obtained as a result of the } \\
\text { experiments made in that area are used. But it } \\
\text { turns out that even the atom has come to form } \\
\text { smaller constructions (quarks). This information } \\
\text { may change in the future." }\end{array}$ \\
\hline
\end{tabular}

ÖA: "The theory may lose its validity, but the law is unchangeable. The Thomson atomic model has changed and evolved into Bohr. The theory of evolution is not widely accepted. The gravity is accepted by everyone."

ÖMA: "A scientific theory can change. But a scientific law cannot change. For example, it is enacted that the speed of light will not change in any reference system. However, the concept of "captivity" is still a theory. Because there are still doubts as to whether or not they exist."

ÖMA: "Scientists have expressed the atom's structure in different ways. For many years different opinions have been raised about atomic structure. For example, Thomson, Dalton, Bohr atomic model. Today, as technology advances, atomic structure becomes definite. For example, Thomson, who simulates atom as a grape cake, thinks grapes as an electron."

ÖR: "Scientists are confident about the atom by doing many experiments. In order to say this state of atom, many theories have been formed experiments have been developed with the most comprehensive information obtained by the development of science. While scientists decided what the atom looked like, previous scientists' experiments on the atom investigated and did information. As a result, the atomic structure has been changed by correcting the wrong places. The atom is already simulated with grape cake etc. This thought has changed with science and today's situation has occurred."

ÖH: "Of course, they have done a lot of experiments about these scientific considerations. They were very impressed by each other's previous scientists before they could be sure. For example, there are many atom models. Thomson, Bohr, Dalton, modern atom theory. They have all conducted research in turn and have been finalized by adding the work of previous scientists. Just like the grape cake model ..."

Ös: "Atom was first described as bubbles in a mushroom stopper. Grape cake, Dalton atom model, Thomson atom model, Rutherford atom models were developed with microscope. As time goes by, the points for which the adequacy of information is unexplained are determined. Thanks to the developing technological materials they are sure of themselves." 
ÖBA: "Similar features are set out. Look at information such as appearance, genes, chromosome numbers."

ÖAA: "To be able to decide whether or not they are species, efficient fertilization can be obtained when they are mated with each other, Such a description has been made by taking advantage of these properties."

ÖP: "Of course, according to the law, which are in the direction of the studies done, they become evidence. For example, experiments are being made by crossing the peas. Then it is done with different plants and the results are compared and a certain traits are revealed."

ÖAA: "An event can have multiple causes. If a law is reached, the theories can be reached by going out of the way. Having two different theories brings more than one cause and hypothesis."
ÖBB: "Scientists have set out from the similarities between species. They can determine which species belongs to each other by looking at whether or not living things are tailed or living in poultry, hair, water, or land. For example, they can determine which species belongs by comparing them. For example, felids, tears, monocotyledons, dicotyledonous plants can be divided into species according to their different characteristics."

ÖS: "Experiments were sure to observe to be sure. This judgment is reached as a result of observations made in the laboratory or in the natural environment. For example, horse and donkey mating does not produce fertile progeny. But the mating between the wolf and the dog produces fertile progeny. As a result of long-term observations and follow-up, special evidence is reached."

ÖA: "They have to have different thoughts and
investigate different assumptions because they make different judgments despite reaching the same data. One of the characteristics of being a scientist believes. Different scientists believe in different assumptions and pursue their work in this framework. This situation is like the situation between the coming of man and the theory of creation."

ÖR: "Every scientist's personal opinion is an event such as scientific knowledge transfer. The data used and the same data obtained indicate that the dinosaurs have disappeared with too much temperature and extinction. Whether it's a volcano or a meteor is the science's thought. This event cannot be tried and the evidence of that time or the narrative of the story cannot be found." 
ÖM: "Science is universal. Although social and cultural values try to influence science, it is universal. For example; Gravity exists for a culture and cannot disappear for a different culture."

ÖT: "Science is universal. Because there is no science that changes according to environmental conditions. There is a science that everyone accepts (universal gravitation - gravity is an example)."

ÖR: "I think science is universal because scientific phenomena are studied by scientists in many different cultures and societies. Scientific events are always accepted by all societies as they are true and are expressed with proofs."

ÖG: "Science is influenced by the society we are in. Everything that a person has is the effect of his life. Even what he wondered may change according to the social life. People living in the poles may be interested in ice structure. Ice can build houses, tools."
ÖZ: "It is influenced by the social and cultural values of science. Because science is made to improve living conditions to improve people, it is affected by the environment. For example; He published his Copernican work towards the end of his life. Because he knows the reactions of the church and its surroundings. For this reason, he stated that the information he wrote in his foreword is only correct as philosophy. So he did not want to take the reaction. We can give Galileo the same status."

ÖBB: "Science is influenced by social and cultural values. It may remain in the face of the world. Factors that occur with social and cultural values can affect knowledge positively or negatively. For example, in the 19th century, religion and science were in war. The greatest reaction to Darwin's theory of evolution came from religious circles. Here we come to the conclusion that religion is influenced by consciousness."

ÖM: "Science has been influenced by social and cultural values in the first years. There is a great deal of influence especially on religion. For example, observations made with the Galileo telescope found Jupiter in various jurisdictions such as the moon, the earth turning around the sun. But at that time the church put it before the court twice, saying it was contrary to the sacred book Joshua."

ÖGA: "Yes they are. Examples are Rutherford's ÖP: "It's based on your imagination. They imagine the answer to a curious question before actually hypothesizing it. They use their creativity and imagination during planning and editing. The result of setting up the experiment setup and the result of the experiment are actually using the creativity. Einstein created the magnetic field created by magnetism with imagination in his head and achieved it."

ÖBB: "Yes, scientists use imagination and creativity. If not, many laws would not exist. They experimented and explored something abstract using their own wisdom, creativity and imagination, and turned it into a concrete truth. For example, in the Thomson atomic model, the grape cake converts the abstract atomic structure into a concrete wisdom by visualizing it."

ÖH: "They are using it. Every scientist was wondering about using his imagination. For example, as Newton wonders how he would fall into his head while sitting under a tree, as Archimedes wonders how the stone could survive on the water. Newton has found its gravitational force with this curiosity, and Archimedes has found the force of lifting water."

\section{b) Results of the explicit-reflective nature of science teaching experimental group}

The frequency distributions of answers given by the participants to the VNOS-C questionnaire before and after the explicit-reflective nature of science teaching course are given below (Table 4). 
Table 4.

Frequency distribution of prospective science teachers' VNOS-C results pre and post explicit-reflective NOS teaching implementation

\begin{tabular}{|c|c|c|c|c|c|c|c|c|c|c|c|}
\hline Components & Timing & & 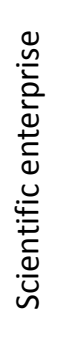 & 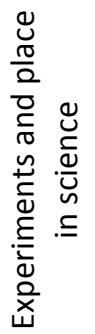 & 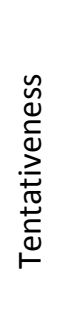 & 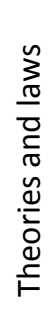 & 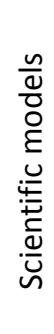 & 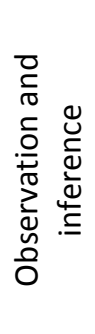 & 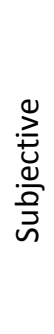 & 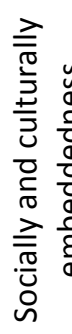 & 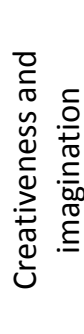 \\
\hline \multirow{6}{*}{ Claim } & \multirow{3}{*}{ Pre-implementation } & None & 18 & 3 & 10 & 3 & 20 & 22 & 25 & 17 & 19 \\
\hline & & Weak & 18 & 31 & 23 & 33 & 17 & 13 & 15 & 19 & 17 \\
\hline & & Strong & 4 & 6 & 7 & 4 & 3 & 5 & 0 & 4 & 4 \\
\hline & \multirow{3}{*}{ Post-implementation } & None & 12 & 0 & 3 & 2 & 11 & 11 & 16 & 7 & 10 \\
\hline & & Weak & 12 & 27 & 21 & 20 & 28 & 25 & 19 & 20 & 19 \\
\hline & & Strong & 16 & 13 & 16 & 18 & 1 & 4 & 5 & 13 & 11 \\
\hline \multirow{6}{*}{ Reasoning } & \multirow{3}{*}{ Pre-implementation } & None & 36 & 23 & 25 & 34 & 32 & 30 & 38 & 31 & 31 \\
\hline & & Weak & 3 & 14 & 13 & 5 & 4 & 9 & 2 & 9 & 9 \\
\hline & & Strong & 0 & 3 & 2 & 1 & 4 & 1 & 0 & 0 & 0 \\
\hline & \multirow{3}{*}{ Post-implementation } & None & 15 & 2 & 7 & 12 & 22 & 14 & 23 & 14 & 20 \\
\hline & & Weak & 23 & 33 & 26 & 20 & 18 & 25 & 17 & 22 & 17 \\
\hline & & Strong & 2 & 5 & 7 & 8 & 0 & 1 & 0 & 4 & 3 \\
\hline \multirow{6}{*}{ Data } & \multirow{3}{*}{ Pre-implementation } & None & 39 & 35 & 35 & 36 & 35 & 38 & 39 & 34 & 36 \\
\hline & & Weak & 1 & 5 & 4 & 2 & 3 & 2 & 1 & 6 & 4 \\
\hline & & Strong & 0 & 0 & 1 & 2 & 2 & 0 & 0 & 0 & 0 \\
\hline & \multirow{3}{*}{ Post-implementation } & None & 29 & 17 & 19 & 18 & 30 & 34 & 31 & 28 & 28 \\
\hline & & Weak & 11 & 22 & 18 & 16 & 10 & 5 & 9 & 11 & 11 \\
\hline & & Strong & 0 & 1 & 3 & 6 & 0 & 1 & 0 & 1 & 1 \\
\hline \multirow{6}{*}{ Warrants } & \multirow{3}{*}{ Pre-implementation } & None & 40 & 40 & 40 & 40 & 40 & 40 & 40 & 40 & 40 \\
\hline & & Weak & 0 & 0 & 0 & 0 & 0 & 0 & 0 & 0 & 0 \\
\hline & & Strong & 0 & 0 & 0 & 0 & 0 & 0 & 0 & 0 & 0 \\
\hline & \multirow{3}{*}{ Post-implementation } & None & 40 & 40 & 40 & 40 & 40 & 40 & 40 & 40 & 40 \\
\hline & & Weak & 0 & 0 & 0 & 0 & 0 & 0 & 0 & 0 & 0 \\
\hline & & Strong & 0 & 0 & 0 & 0 & 0 & 0 & 0 & 0 & 0 \\
\hline \multirow{6}{*}{ Rebuttals } & \multirow{3}{*}{ Pre-implementation } & None & 40 & 40 & 40 & 40 & 40 & 40 & 40 & 40 & 40 \\
\hline & & Weak & 0 & 0 & 0 & 0 & 0 & 0 & 0 & 0 & 0 \\
\hline & & Strong & 0 & 0 & 0 & 0 & 0 & 0 & 0 & 0 & 0 \\
\hline & \multirow{3}{*}{ Post-implementation } & None & 40 & 40 & 40 & 40 & 40 & 40 & 40 & 40 & 40 \\
\hline & & Weak & 0 & 0 & 0 & 0 & 0 & 0 & 0 & 0 & 0 \\
\hline & & Strong & 0 & 0 & 0 & 0 & 0 & 0 & 0 & 0 & 0 \\
\hline
\end{tabular}

When Table 4 is examined, it can be seen that the majority of prospective teachers are able to make weak arguments before the application, but the number of participants with weak arguments is still high despite the increase in the number of strong arguments. Considering the reasoning component, it was determined that the majority of the prospective teachers failed in reasoning, but more than half of the participants did poorly reasoning after the application. It has been determined that the teacher candidates cannot show much improvement compared to the data prior to the application but only one 
fourth of the teacher candidates can provide weak data. When the reasoning and data components are evaluated together, it has been determined that the majority of the prospective teachers failed in evidence but more than half of the participants were able to provide weak evidence after the application. It was found that none of the prospective teachers showed improvement in providing and refusing support. In order to support these frequency data, the following citation is given for each questionnaire and given under separate columns before and after the application.

Table 5 summarizes the answers given by the participants to the questionnaires on the nature of science applied to prospective teachers before and after explicit-reflective nature of scienceeducation. In the preliminary application, teacher candidates were given answers such as science, which is based on experimentation and observation based on scientific knowledge, which is different from other research areas. The majority of participants think that experiments are needed to develop science. They have supported these claims with the need for experiments for the demonstrability, experimentability, development and change of science. A large part of the teacher candidates think that scientific theories will change over time. They have supported these claims with the technological developments brought about by the time of scientific knowledge. They said that they could change over time because they could not explain some events exactly. The vast majority of prospective teachers state that there is a difference between theory and law. Teacher candidates are convinced that theories for which theories are not definitive are precise information, so theories that the laws cannot refute will eventually be refuted. The question of how the prospective teachers are using scientifically specific information about the atom and how confident they are about the structure of the atom is that they use evidence that confirms this knowledge through experimentation as a result of time-developed theories and models. Teacher candidates have tried to support how scientists are certain about a species by examining the genetics of the organism, the offspring they give, and the experiments they have done, as to how they are confident about what they are about. Teacher candidates generally did not respond to the question of how scientists achieved different outcomes by looking at the same results and the same data, and respondents expressed that the scientists were influenced by the culture they were living in and the working environment. The majority of prospective teachers claim that science is universal whether science is universal. Besides, they expressed that science is influenced by society and cultural values. Teacher candidates claimed that imagination and creativity play an active role in almost every stage of science.

Teacher candidates stated that in their post-application answers, science made experiments and research instead of accepting different characteristics from other research fields directly as in the verbal fields such as religion and philosophy. Teacher candidates expressed the need for scientific experimentation to develop science and obtain valid and reliable information. The vast majority have also tried to support the importance of experimenting with the formation of scientific knowledge by giving examples from scientific experiments and inventions. Teacher candidates have been arguing that scientific theories may change over time. Some of the prospective teachers state that there is still a hierarchical relationship between them, as it was before applying it, and that the law is unchangeable, in relation to the difference between scientific law and theory. However, according to the answers before the application, some of the teacher candidates in the post-practice answers were often said to be unable to be changed and that it could change in the light of the new evidence. Teacher candidates have argued that can be sure based on the results of hypotheses, experiments, and observations. Teacher candidates have stated that scientists are observing species when researching species, using features similar to species, and being able to make certain of the inferences and species based on them. They also said that they considered the ability of the species to yield fertile fertilizers when they mated. Teacher candidates have tried to explain to scientists how different individuals reach different results using the same data, from the difference between the preliminary of the scientists, because each individual has different imagination. The majority of teacher candidates expressed that scientific knowledge is influenced by social and cultural values and the philosophical and religious values of the society in which they are in. They also expressed that science is influenced by imagination and creativity. 
They have tried to exemplify these claims by using inventions and inventions of scientists such as Einstein and Newton. In Table 5 below, the pre- and post-implementation views of students whose answers are conspicuous and understandable are given.

Table 5.

Quotations of prospective science teachers' opinions about nature of science Pre- and Postimplementations in argumentation based explicit-reflective nature of science teaching group Opinions before implementation Opinions after implementation

EE: "Science is an effort to find laws linking the world's events through reasoning based on observation and observation. One of the greatest features that distinguishes it from other research is experimentation and observation. It is information that is made by doing and living and science is a constantly changing concept."

FÖ: "It is the sum of the information that makes the research, investigates the cause-effect relation of the events, produces the solutions, and provides science different is the gathering of information with observations and experiments." experimentation." the meaning of the environment. What makes

$\mathrm{H}$ : "Science is a process that results in people approaching nature with an outlook contrary to the views accepted as a result of observing their environment. Religion is different from a science of physics. The physicist does not accept an event directly. He conducts experiments and research in that subject. In the science of religion there are some definite judgments which are not subject to

S: "Science; Researching the phenomenon with curiosity, is a branch that contains many subjects designed to facilitate human life. While these phenomena are being investigated, various experiments and observations are used. What makes a physics branch different from philosophy or religion is based on experiments."

EK: "Experiments are needed to develop scientific knowledge. For example, Magellan proved by experimenting that the Earth is round. When Newton dropped apples, he proved this idea by doing a series of new experiments."

@ MU: "Experiments are needed. Experiments are conducted to develop scientific research. Without experiments, there is no definite opinion. Going to the Moon is not known without trial, for example."

EE: "Yes scientific theories may change. Because science is a constantly changing concept. As technology progresses, people may find that it is not the case when they examine the previously accepted theories. Thus theories may change." DK: "Theories cannot be changed like laws. There is validity, but there are cases where he cannot explain exactly. We strive to learn quantum theory. Because there are more things that cannot be achieved, the matter behaves differently in that dimension. Theories can be refuted, developed."
C: "Experiments are needed to develop scientific knowledge. Because scientific information must be valid and reliable information. Experiments are needed to ensure that valid and reliable information cannot be obtained precisely through observations."

EK: "The development of scientific knowledge requires experimentation. Because after Newton has fallen the apple, he investigated whether the fall of the objects was related to altitude. Then another scientist proved it by dropping the ball from different heights into the clay."

CK: "After scientists have developed a scientific theory, the theories may change. The number of planets was 7 while it was be 6 . The theory here has changed. Because the observations or studies made when the theories are introduced may not be definite. But today's scientists may have proven them by making them more sensitive."

HY: "Scientific theory, other validity can be changed with high evidence. Although the theory of evolution seems to have proved valid, it may change with the investigations made. For example, the theory that the Earth is like a round tray has changed." 
ZG: "The theory may change, but the law is accepted. For example, Newton's law of gravity was accepted when the theory of evolution was constantly changing."

BP: "Scientific law is a proven theory, yet an unproven scientific compilation. For example, the gravitation law, the Newtonian law of motion, the theory of special relativity and the theory of evolution can be given as examples."
BP: "Yes there is. The theory of evolution is an unproven and controversial issue. The Kepler Law is a proven knowledge of the world's movement and has been accepted by all."

FÖ: "Both can change. The law is known as unchangeable. But with new information they can change. Newton's first law and atomic theory are examples of this."

DK: "Yes there is a difference. A scientific law usually does not change. Newton's laws of motion, for example, are always in every case. A scientific theory can be refuted as it can be developed. For example, we say that there is a particle that passes the speed of light."

DK: "Scientists have done a lot of work when deciding about the structure of the atom, and these studies have always progressed in a gradual way. The precedent is likened to the model of the atomic grape cake model solar system, which is likened to an empty sphere. Each work contributed to the development of scientific knowledge about the atom. Work has been done by taking advantage of the special cases of the material."

Y: "Researches have been done for many years about atomic structure. Atomic structure was revealed by prediction. First of all, scientists started by imagining that electrons could be mobile and then supported it with experiments. Scientists have discovered the shape of an atom because of the charge of protons, neutrons, and electrons. They came out of the action of these particles."

DK: "Scientists have observed that this group makes observations and that the other group does not give fruitful fertility to the mating group. They have interpreted according to the situations that are made as a result of the work done. When deciding, they used the structure of the living thing, their genes, and the progeny they gave."

CS: "They did experiments. For example, we are observing that the offspring who are breeding when they accept the same species as the donkey and the horse are inefficient. Scientists are also on the road from hypotheses."
HY: "They put scientific theories into scientific law by making experiments and observations. Of course, this proposal was formed at the end of their experiments. It can be so sure. They used the information generated by protons and neutrons around a core nucleus in the center and electrons circulating around it."

TA: "Experiments, assumptions, observations, hypotheses they make are sure of what they do. The result is concrete information on your hands. They have the chance to prove it right or wrong."

YY: "They may have learned this by pairing animals. Because species can make efficient prostitution among themselves. Horses and donkeys are separate species and live mules born in their mating. Mule is a vicious animal. There is no efficient prostitution here. Scientists explain the concept of logic and a series of

BK: "It has been understood that many species of fertile offspring have been tried to learn by many experiments, and it has been understood that similar organisms will produce fertile ones only by their own species. By looking at the gene maps of all the organisms, their characteristics can be revealed and it can be concluded which kind of product is fertile." experiments." 
AE: "We can say that scientists have different theories. The fact that hypotheses reach the same data and produce different results may depend on the place, culture, working environment, thought style of these scientists."

SA: "Because the idea that everyone is trying to achieve is different and precisely because science has not improved so much, there are differences. The exact results, the evidence is not as good as the old one."

\footnotetext{
SB: "Actually it reflects both. In other words, it reflects social and cultural values. Therefore, science can also shape the social structure of a person's culture. Science must be universal. It is not true that it is entirely connected to the sociocultural structure. The cultural social structure of each community may be different. But everyone on science can join in the same place. Because science is based on evidence and facts."

BP: "It is influenced by social and cultural values. In the light of science, it is dominant that there is no other occupation by science in distant parts. This prevents the acceptance of science from developing in place."
}

AY: "Yes, scientists use their imagination and creativity at every step. Scientists decide to investigate objects that are interested in objects around them. He designs the experiment on creative thinking. They perform experiments by collecting data accordingly. Because if they do not have the imagination, they do not know how to go about their curiosity. Creativity is the foundation of experiments."

CS: "Scientist is curious. He dreams. Yes he uses imagination and creativity. For example, they imagined its structure without seeing the sun. They use their powers more in the planning phase."

\section{Discussion, Conclusion and Implementation}

Argumentation was seen as an effective way of analyses and interpretation of expressions in science classes. Using of scientific argumentation in courses help evaluation and formation of students' and teachers' scientific knowledge claims (Duschl, 2007). Similarly, it was investigate how affect on conceptual understanding prospective science teacher engage in nature of science teaching approaches and how reflect on formation of written arguments about prospective science teachers' nature of science opinions. Prospective science teachers' written arguments about nature of science were investigated by using Turkish argumentation model (Aktamış \& Hiğde, 2015). Prospective science teachers were engaged in implementation courses including Turkish argumentation model.

Written arguments about prospective science teachers' opinions towards nature of science were investigated in accordance of claim, data, evidence (data and reasoning), warrant and rebuttals. Consistent with the findings of previous studies, the results of the present study demonstrated those 
prospective science teachers' written arguments towards views about nature of science before implementation were found weak but strong ability to make argumentation was found after implementation. This findings could not be explained by not only engaging in argumentation based teaching but also related with development of epistemological knowledge about nature of science (Bell \& Lederman, 2003; Sandoval, 2003; McDonald, 2010).

Prospective science teachers enrolled in argumentation based teaching could not provide evidences for their claim before implementation but more half of participants could provide strong evidence for their claim after implementation, only small number of participants could not provide evidences. Also, participants in explicit-reflective teaching could provide weak evidences for their claim. It can be inferred that argumentation based explicit-reflective NOS teaching and explicit-reflective NOS teaching were effective to represent appropriate data by using reasoning ability for prospective science teachers. Argumentation based experiment group provide more evidence than explicit-reflective group because argumentation experiment group enrolled in argumentation and history of science embedded activities. Therefore, argumentation group participants used more evidence about history of science and more examples form history of science. Consistent with these findings of the current study, McDonald (2010) found that prospective teachers enrolled in explicit-reflective nature of science teaching and argumentation based teaching could provide evidences by using appropriate data.

It was found that participants enrolled in argumentation based teaching stronger data than ones enrolled in explicit-reflective based teaching. These findings could be explained with using examples from history of science and experimental data properly to support own their claims. Also, development of prospective science teachers' ability to use data may be associated with engaging in argumentation based historical activities and examples related with formation of scientific knowledge (Sandoval, 2003). In addition, prospective science teachers provide examples from engaged in activities during argumentation based teachingas data (Khishfe, 2014).

In providing warrants, argumentation based group showed a few development but explicit reflective group did not show any development. In providing rebuttal, each of groups did not show any improvement. Because prospective science teachers firstly engaged in argumentation based teaching, providing rebuttal in written arguments about nature of science was difficult, the lack of prior learning about argumentation among students, prospective science teachers' knowledge about nature of science was not improved to provide warrants and rebuttals (Kelly et al., 2008). In addition, there was pedagogical lacking of teachers to use argumentation in their class and lacking of experience of teachers about argumentation (Driver, Newton \& Osborne, 2000). Students and teachers have not been improved to assess scientific topic and knowledge with multiple perspectives so they could not provide advance level of argument and not reasoning (Demircioğlu \& Uçar, 2014). In the light of findings of this study, engaging in argumentation based teaching cause not advance level but intermediate level of development of written arguments about nature of science. In a similar study, teachers improve intermediate level of argumentations to increase the quality of argumentation in two and a half years of project (Erduran, Simon \& Osborne, 2004). When compared with this study and current study time, current study realized in a short time such as three months can be regarded as a significant constraint. To improve argumentation level of prospective science teachers, it was suggested that they engage in activities developing conceptual and epistemological perspectives for science and increasing metacognitive awareness towards nature of science. Instead of direct questions about the nature of science, prospective sciences teachers can justify their own views about nature of science by using activities including separated into argumentation components easily and distinguish the argumentation components (claim, data, evidence, warrant and rebuttal). The current study can be tested with middle school and high school students. While this study can be experimental support for studies work together about nature of science and argumentation, it was suggested to study about how teachers can use argumentation to teach nature of science in their classrooms. 


\section{Türkçe Sürümü}

\section{Giriş}

Günümüzde eğitime yönelik bakış açısında ortaya çıkan değişiklikler fen eğitiminin amaçlarında da önemli değişimlere sebep olmaktadır. Yeni bilimsel bilgilerin ortaya çıkma hızı dikkate alındığında tüm öğrencilere bu bilgilerin hepsinin öğretilemeyeceği açıktır (Milli Eğitim Bakanlığı [MEB], 2013). Bu sebeple birçok ülkede meydana geldiği gibi Türkiye'de de yeni öğretim programlarında tüm bilgileri aktarmak yerine bu bilgilere ulaşma becerileri, bilim okuryazarlığı ve bilimin doğası ön plana alınmıştır (Milli Eğitim Bakanlığı [MEB], 2013). Bilimsel kavramlar ve becerileri içeren bir üst başlık olan bilim okuryazarlığının önemli alt başlıklarından birisi de bilimin doğasıdır (Köseoğlu, Tümay \& Budak, 2008). Genel olarak ele alındığında, bilimin doğası ile bilim epistemolojisi, bilmenin bir yolu olarak bilim veya bilimsel bilginin gelişiminin doğasında var olan değerler ve inançlar kastedilmektedir (Lederman, 1992). McComas \& Olson, (1998) ise bilimin doğasının, psikolojisi, sosyolojisi, bilim tarihi ve felsefesi gibi bilimin çeşitli çalışma alanlarını bir araya getirdiğini ve "bilim nedir, nasıl işler, bilim insanları nasıl çalışır, sosyal ve kültürel bağlamların bilime etkisi nedir?” gibi konuları ele aldığını ifade etmiştir.

Bilimin doğası ile ilgili son yıllarda literatürdeki ilgili çalışmalar incelendiğinde herkes tarafından kabul gören tek bir tanım olmadığı görülmüştür. Ancak bilimin doğası hakkında yapılan çalışmalar incelendiğinde aşağıda verilen genel hususların bilimin doğasını ve bilimin doğasının unsurlarını en iyi şekilde yansıttığı söylenebilir;

- Bilimsel bilgiler deneylerle test edilmektedir. Bu yüzden bilimsel bilgi olgusal temellidir. Gözlem ve çıkarım birbirinden farklıdır. Bilim insanları da gözlem ve verileri kullanarak bir iddia oluşturmak için delillerin iddialarını nasıl gerekçelendireceğine önem verirler. Bu süreçte bilim insanları gözlem ve veriler hakkında çıkarımlar yaparlar ve bu nedenle bilimsel bilgi sübjektiftir (McComas, 2004; Scwartz, Lederman \& Crawford, 2004; Lederman, 2007; Bell, 2009).

- Bir konuya yönelik aynı veriler bulunsa da farklı çıkarımlarda bulunulabileceğinden farklı yarışan teoriler ortaya çıkabilir. Bu nedenle bilim insanları da bu teorilerden hangisini destekleyeceğine karar verirken mevcut kanıtlara en uygun olan teoriyi seçer, devamlı sorgular, bilgiyi geliştirir ve değiştirir. Bu yüzden bilimsel bilgi değişeme açık bir doğaya sahiptir (Abd-El-Khalick, Bell \& Lederman, 1998; Khishfe \& Abd-El-Khalick, 2002; McComas, 2004; Scwartz, Lederman \& Crawford, 2004; Lederman, 2007; Bell, 2009).

- Bilim insanları bilimsel bilgiyi oluştururken hayal gücü ve yaratıcılığın etkisinde kalırlar (Abd-ElKhalick, Bell \& Lederman, 1998; Khishfe \& Abd-El-Khalick, 2002; McComas, 2004; Scwartz, Lederman \& Crawford, 2004; Lederman, 2007; Bell, 2009). Ek olarak bilim insanları da toplumun ve bir kültürün parçası olduğu için bilimsel bilgi, bilimin, bilginin oluşturulduğu toplumun sosyal ve kültürel değerlerinden etkilenir (McComas, 2004; Scwartz, Lederman \& Crawford, 2004; Lederman, 2007; Bell, 2009).

Ayrıca, Driver, Newton \& Osborne (2000) fen eğitiminde bilimin doğasının öğretimini insanların bilimi ve teknolojik değişimleri takip etmek ve anlamak için, sosyo-bilimsel konularda ve süreçlerde karar verebilmek ve değerlendirebilmek için, bilimsel toplumun normlarını ve ahlaki kurallarını anlamak için ve fen eğitiminde fen içeriğinin başarılı şekilde öğretilmesi için gerekli olduğunu ileri sürmüştür. Bilimin doğasının fen eğitimindeki öneminin ne olduğunun yanında nasıl öğretileceğine ilişkin birçok farklı yaklaşım bulunmaktadır. Alan yazın incelendiğinde bilimin doğası öğretiminde kullanılan yaklaşımların; tarihsel, dolaylı ve açık-düşündürücü yaklaşım olduğu görülmektedir (Abd-El-Khalick \& Lederman, 2000; Khishfe \& Abd-El-Khalick, 2002). Ancak son yıllarda sorgulama odaklı ve argümantasyon odaklı öğretimin öne çıkmasıyla birlikte açık-düşündürücü yaklaşım odaklı bilimsel argümantasyon ile öğretimin araştırma konusu olduğunu görülmektedir (Çetin, 2014; Khishfe, 2014; Demircioğlu ve Uçar, 2014). illköğretim kurumları Fen Bilimleri ders programında da temel yaklaşım olarak derslerin planlanmasında ve 
uygulanmasında öğrencinin aktif katılımının sağlandığı öğretmenin ise daha çok rehber rolünü üstlendiği argümantasyona yer verilmiştir. Dolayısıyla da öğretmenlerden, öğrencilerin düşüncelerini özgürce açıklayabildikleri, farklı gerekçelerle bu düşüncelerini savunabildikleri ve karşıt görüşleri çürütmek amacıyla karşıt iddialar oluşturabildikleri ortamı oluşturmaları beklenir. Ayrıca bu süreçte öğretmenlerden öğrencilerin oluşturdukları iddia ve karşıt iddialarını uygun gerekçelerle desteklemelerini sağlayııı rehber ve yönlendirici rolü üstlenmeleri beklenmektedir. Bunun sonucu olarak fen eğitiminde argümantasyon destekli öğretimin önemi ortaya çıkmaktadır.

\section{Açık-Düşündürücü Bilimsel Argümantasyon ile Bilim Öğretimi}

Bilimsel argümantasyon hakkında yaygın bir kavram yanılgısı bilimsel argümantasyonun basitçe tartışma veya karşılıklı iddialar öne sürme olarak görülmesidir. Aslında argümantasyon, iddiaları dayandıkları veriler ile ilişkilendiren uygun gerekçeleri yapılandırma süreci olarak tanımlanabilir (Toulmin, 2003). Argüman ve argümantasyonun literatürde kesin bir tanımı olmamakla birlikte Toulmin (2003) tarafından bir iddia ve beraberindeki gerekçelendirmeler olarak tanımlanmaktadır. JimenezAleixandre ve Erduran (2007) argümantasyonu bireysel ve sosyal açıdan iki şekilde tanımlamıştır. Bireysel açıdan bir kişinin gerekçelendirdiği herhangi bir iddia, bu iddia hakkında kişinin oluşturduğu bir görüş veya kişinin bir argüman oluşturma süreci olarak düşünülebileceği tanımını yaparken, sosyal açıdan bir konuya yönelik karşıt görüşlere sahip kişilerin tartışması ve birbirlerini çürütmesi olarak tanımlamıştır. Argümantasyonun fen eğitimindeki uygulamaları incelendiğinde ise yapılan çalışmalar zayıf argümantasyon becerileri, verileri ve destekleyicileri önemsememe gibi özel sınırlııkları, çıkarımlara ve yorumlamalara çok yer verilmesi, gerekçe ve veri kullanmadan sonuca gitme, karşıt kanıtları değerlendirmedeki eksiklik gibi sınırlılıkların olduğu görülmüştür (Driver, Newton, \&Osborne, 2000). Ayrıca yapılan çalışmalarda sınıf içi uygulamaların öğretmen merkezli öğretime uygun olduğu, öğrencilere daha az tartışma ortamı sağlandığı, öğrencileri argümantasyona dâhil edecek ortam oluşturulmadığı bulunmuştur (Newton, Driver, \& Osborne, 1999). Fen eğitiminde argümantasyon odaklı sınıf içi uygulamaların zamanla açık-düşündürücü argümantasyon eğitimine doğru kaydığı görülmektedir (Cetin, 2014, Khishfe, 2014; Zohar \& Nemet, 2002). Açık düşündürücü yaklaşımda argümantasyon yapısal, işlevsel ve uygulama olarak öğrencilere argümantasyonu değerlendirme kriterleri temel alınarak açıkça direkt olarak tanıtılır ve öğretilir (McDonald, 2010). Bilimsel bağlamda yapılan ve açık argümantasyonun uygulandığı araştırmalarda öğrencilerin argümantasyon becerilerinde ve argümantasyon kalitelerinde artışın olduğu saptanmıştır (Bell\&Linn, 2000; McDonald, 2008; Yerrick, 2000; Zohar \& Nemet, 2002). Bu nedenle açık düşündürücü argümantasyon yaklaşımı ve kullanılan bilimsel bağlamın öğrencilerin becerilerini ve oluşturdukları argümantasyonların kalitelerini geliştirmek için etkili olduğu görülmektedir. Ayrıca bilim tarihini göz önüne alındığında, bilimde incelenen fenomenle ilgili aynı verilere bakılarak farklı teorilerin öne çıktığı görülmektedir. Bilim insanları da bu teorilerden hangisini destekleyeceğine karar verirken, argümanların hangisinin var olan kanıtlara uygun olduğuna dikkat eder. Benzer şekilde öğrencilerde sadece iddiaları ve sonuçları öne sürmek yerine iddialarını en iyi şekilde kanıtlara uygun oluşturmayı ve diğer karşıt iddialarında zayıfıklarını belirleyerek eldeki kanıtlara dayalı doğru gerekçelendirme ile kendi iddialarını oluşturabilmelidir (Driver ve diğ., 2000). Bilimsel argümantasyonda öğrenciler bilimsel bir konuda iddialar ortaya koyar, destekler, eleştirme, değerlendirme ve gözden geçirip düzeltmeyi içeren bilimsel argümantasyon sürecine katılırlar, bilimi devamlı olarak iddiaların öne sürüldüğü, sorgulandığı ve genellikle geliştirildiği veya değiştirildiği bir süreç olarak görebilirler (Cetin 2014; Khishfe, 2012). Bilimin bu değişen, gelişen ve sorgulanan yapısı bilimin doğası ve bilimsel argümantasyonu birleştiren özellikler olarak görülmekte, argümantasyonun öğrencilerin bilimin doğasını anlamasına yardım ettiği belirtilmekte ve ikisinin birleştirildiği birçok çalışmayla karşılaşılmaktadır (Jimenez-Aleixandre\& Erduran, 2007; McDonald, 2008; McDonald \& McRobbie, 2011; Khishfe, 2014).

Son zamanlarda bilimin doğası bağlamında yapılan argümantasyon temelli çalışmalarda öğrencilerin hem bilimin doğasına yönelik görüşlerini hem de oluşturdukları argümantasyon kalitelerini artırmada açık düşündürücü argümantasyon odakı öğretimin uygulanmasının etkili olduğu görülmektedir (Cetin 
2014; Khishfe, 2012, 2014; McDonald, 2008; McDonald \& McRobbie, 2011). Literatür incelendiğinde bilimin doğası ve argümantasyonun bir arada araştırıldığı çalışmalar iki başlık altında toplanmaktadır. Birinci gruptaki çalışmalar, öğrencilerin bilimin doğası hakkındaki görüşlerinin argümantasyon kalitesi üzerindeki etkisini ve öğrencilerin argümantasyon oluşturmadaki problemlerini incelemektedir (Bell \& Lederman, 2003; Sadler, Chambers, \& Zeidler, 2004; Walker \& Zeidler, 2004). İkinci gruptaki çalışmalar argümantasyonun öğrencilerin bilimin doğasına yönelik görüşlerine yansımalarını ve etkilerini araştırmaktadır (Bell \& Linn, 2000; Yerrick, 2000; Ogunniyi, 2006). Bu çalışmalara ek olarak argümantasyon bilimsel epistemolojiyi öğrenmek için bir mekanizma olarak görülmektedir (Sandoval \& Millwood, 2007). Bilimsel argümantasyon üzerindeki etkisinin incelendiği birçok çalışmada sözlü ve yazılı argümantasyona yansımalar olarak yoğun şekilde çalışılmıştır. Fen eğitimi bağlamında argümantasyonun amaçlarından biri de öğrencilerin iddialarını desteklemek için kanıtları ve destekleyicileri kullanma yeteneklerinin geliştirilmesidir (Kelly, Regev, \& Prothero, 2008; McDonald, 2008; Sandoval \& Millwood, 2007; Yore, Florence, Pearson, \& Weaver, 2006).

Sözlü argümantasyona ilişkin araştırmalar sonucunda işbirlikli sorgulama veya problem çözmede genellikle grup çalışmalarında öğrencilerin destekleyicileri ve kanıtları kullanmadan tipik iddiaları oluşturdukları görülmektedir (Erduran, Simon \& Osborne, 2004; Jimenez-Aleixandre, Rodriguez, \& Duschl, 2000; Kelly ve diğ., 2008). Ayrıca yazılı argümantasyona yönelik yapılan çalışmaların öğrencilerin argüman yapılarının incelenmesine, iddialar hakkında nasıl bir düşünce yapısına sahip olduklarının belirlenmesine ve diğerlerinin çalışmalarının analizini belirlemek için önemli bir fırsat sağladığı görülmektedir (Bell \& Linn, 2000; Kelly ve diğ., 2008; Sandoval, 2003). Bilim insanı veya bilim okuryazarı olmasını istediğimiz bireyleri yetiştirmek istiyorsak eğer, bu öğrencileri üretken, bilimin doğasını bilen ve argümantasyon becerilerine sahip bireyler olarak yetiştirmemiz gerekmektedir. Bu nedenle bu bireylerin yetiştirilmesinde de en önemli görev öğretmenlere ve öğretmenleri yetiştirecek eğitim kurumlarına düşmektedir.

Bilimin doğası ile ilgili yukarıda bahsedilen yeni anlayışları öğrencilerin anlamlı bir şekilde kavraması için sınıfta kullanılabilecek en etkin öğretim yaklaşımlarından birinin öğrencileri açık-düşündürücü bilimsel argümantasyon ile bilim öğretimi sürecine katmaktır. Bu bağlamda bu çalışmanın amacı, bilimin doğasına ilişkin argümantasyon destekli açık düşündürücü yaklaşımla ve sadece açık düşündürücü yaklaşım ile yapılan bilimin doğası etkinliklerinin fen bilgisi öğretmen adaylarının yazılı argümanlarının yapısına ve kavramsal anlamalarına yansımasını incelemektir.

\section{Araştırma Modeli}

Yöntem

Öğretmen adaylarının bilimin doğası hakkında oluşturdukları yazılı argümanların kalitesinin belirlenmesine yönelik bu araştırmada deneysel araştırma modellerinden kontrol grupsuz ön test-son test deneysel desen araştırma modeli kullanılmıştır. Bu araştırma modelinde, değişkenler arasındaki neden-sonuç ilişkisi belirlenir (Campbell \& Stanley, 1963). Birinci deney grubunda argümantasyon temelli açık düşündürücü bilimin doğası öğretimi uygulanırken, ikinci deney grubunda açık düşündürücü eğitim uygulanmıştır. Verilerin toplanmasında nitel araştırma teknikleri kullanılmıştır. Öğretmen adaylarına VNOS-C ölçeği uygulanarak bilimin doğasına yönelik görüşlerini ifade ettikleri yazılı argümanları ADADBD öğretimi uygulanan ve ADBD öğretimi uygulanan gruplardan uygulama öncesi ve sonrası olarak toplanmış ve betimsel analiz yapılmıştır.

\section{Katılımcılar}

Bu çalışmaya bir devlet üniversitesindeki 3. sınıfta okuyan 70 (52 kadın, 18 erkek) fen bilgisi öğretmen adayı katılmıştır. 3. sınıftaki öğrencilerin seçilmesinin sebebi olarak öğrencilerin ilk defa bu sınıfta "Bilimin Doğası ve Bilim Tarihi" isimli derse katılmış olmalarıdır. Katılımcılar ADADBD deney grubu 30 kişi (26 kadın ve 4 erkek) ve ADBD deney grubu 40 kişi (26 kadın ve 14 erkek) olarak iki gruba ayrılmışlardır. Sınıflardan biri rastgele olarak ADADBD deney grubu, diğeri ise ADBD deney grubu olarak 
seçilmiştir. ADADBD deney grubuna argümantasyon destekli açık düşündürücü yaklaşım ile bilimin doğası öğretimi uygulanırken, ADBD deney grubuna açık düşündürücü yaklaşım ile bilimin doğası öğretimi uygulanmıştır. Öğretmen adaylarının aldıkları eğitimin yazıı argümanlarının yapısına ve kavramsal anlamalarına yansımaları, uygulama öncesi ve sonrası olarak karşılaştııılmasıyla belirlenmiştir.

\section{Veri Toplama Araçları}

Öğretmen adaylarının 2013-2014 yılı bahar döneminin ilk ve son haftalarında bilimin doğası hakkındaki görüşlerini belirlemek için, Lederman ve diğerleri tarafından 2002 yılında geliştirilen ve Türkçeye Küçük (2006) tarafından adapte edilen Bilimin Doğası Üzerine Görüşler Anketi (Views of Nature of Science Questionnaire) (VNOS) kullanıımıştır. Bilimin Doğası Hakkında Görüşler Anketi-Form C bu çalışmada odaklanılan bilimin doğası boyutlarıyla ilgili 10 adet açık uçlu soru içermektedir. Anket öğrencilere, uygulamadan önce ön test ve uygulamadan sonra son test olarak uygulanmıştır. Ölçekteki sorular bilimin doğası özelliklerinden; bilimsel bilginin deneye dayalı olması, gözlem ve çıkarım arasındaki fark, teori ve kanun arasındaki fark, bilimsel bilginin değişebilirliği, bilimsel bilginin teoriye dayalı olması, bilimsel bilginin üretilmesinde hayal gücü ve yaratıclığın rolü, bilimsel bilginin sosyal ve kültürel yapısı konusundaki düşünceleri ortaya çıkarmaya yöneliktir. Örnek bir soru maddesi; "Bilimsel teori ile bilimsel kanun arasında bir fark var mıdır? Cevabınızı bir örnekle açıklayınız." şeklindedir.

\section{İşlem ve Uygulama}

Araştırmada,Bilimin doğası ve bilim tarihi dersinde bilimin doğasının yedi özelliğine dayalı argümantasyon destekli açık düşündürücü yaklaşım ve açık düşündürücü yaklaşıma yönelik etkinlikler hazırlanmıştır. Ayrıca öğretmen adaylarına bilimin tarihsel gelişimi Mısır-Mezopotamya; antik yunan; ortaçă̆; islam'da bilim; Rönesans; 17-18. YY. 'da bilim; 19-20. YY.' da bilim ve Türklerde bilim dönemleri başıkları altında her hafta bir dönemin felsefi özellikleri ve döneme damga vuran gelişmelerin üzerinde durulduğu tartışma etkinlikleri ve dönem ile ilgili kısa bir video veya drama etkinliği ile desteklenerek işlenmiştir.

Hazırlanan etkinlikler, fen bilgisi öğretmen adaylarına, fen eğitimi reform dokümanlarında belirtilen bilimin doğasının yedi unsuru hakkında bilimsel olarak kabul edilen kavramlar kazandırmayı ve argüman kurma becerilerini geliştirmeyi hedeflemektedir. Bu etkinliklerde öğretmen adayları tüm çalışma boyunca grup çalışması yapmışlar ve her bir etkinlik öğretmen adayları tarafından ortaya atılan bir soru veya bir gösteri ile başlamıştır. Etkinliklerin her biri, öğretmen adaylarının bilimin doğasının yedi özelliğini açık bir şekilde ortaya koyacak ve sınıfta sunulan fikirlerin aktif bir şekilde açıklanmasını ve tartışımasını sağlayacak şekilde tasarlanmışırı. Etkinliklerin bazılarında kullanılan öğretim senaryoları (örneğin, fosiller) ve resimler (örneğin, hileli izler) literatürden alınmıştır (Lederman \& Abd-El-Khalick, 1998; Doğan, Çakıroğlu, Bilica ve Çavuş, 2012). İçeriğin ve bilimsel süreç becerilerinin tartışılmasında, yansıtıcı bilimin doğası unsuru takip edilmiştir. Her bir etkinlikten sonra, bilimin doğasının bazı unsurlarına özellikle dikkat çekilmiş ve yapılan etkinlik ile bu unsurlar arasındaki ilişkiler üzerinde öğrencilerin yansıtma yapmaları ve tartışmaları için kendilerine rehberlik edilmiştir. Bu etkinliklerde bilimin ve bilimsel bilginin yedi özelliği üzerine odaklanılmıştır:
a) Bilimsel bilginin deneysel olması,
b) Bilimsel bilginin değişebilir olması,
c) Gözlem ve çıkarım arasında fark olması,
d) Bilimsel bilginin insan yaratıcılı̆̆ının ve hayâl gücünün bir ürünü olması,
e) Bilimsel bilginin öznel olması,
f) Teori ve kanun arasında fark olması,
g) Bilimsel bilginin sosyal ve kültürel değerlerden etkilenebilir olması.

Etkinliklerin her birinde odaklanılan bilimin doğasıyla ilgili temel kavramlar ve ilgili diğer kavramlar ayrıca açıklanmışırı. Bilimin doğasının öğrencilere kavratılmasıyla ilgili tasarlanan ve uygulanan öğretim etkinliklerinin konusu, içeriği ve işleniş şekliyle ilgili bilgilere aşağıda sırayla ve ayrıntılı olarak yer 
verilmiştir.

\section{ADADBD Deney Grubuna Uygulanan Etkinlikler}

Aşağıda verilen etkinlikler bu grupta ADADBD yaklaşımıyla uygulanmıştır. Uygulama sırasında her hafta bir etkinlik uygulanmıştır.

\section{Etkinlik 1. Bilimsel bilgi değiş̧ir mi?}

Bu etkinlikte, öğretmen adaylarının bilimsel bilginin değişip değiş̧mediği hakkında iddialar oluşturarak bilimsel bilginin niçin değiştiğini tecrübe etmeleri hedeflenmiştir. Etkinlikte öğretmen adaylarına iki iddia verilerek (bilimsel bilgi değişir ve bilimsel bilgi değişmez) bunlardan hangisine katıldıkları ve niçin bunu destekledikleri sorularak deliller sunmaları ve akıl yürütme yapmaları istenmiştir. Daha sonra karşıt görüşün iddialarına karşı çürütücüler vermeleri istenmiştir. Etkinlik sonucunda öğretmen adaylarının bilimsel bilginin değiştiği iddiasını argümantasyon destekli açık düşündürücü yaklaşım ile öğrenmeleri amaçlanmıştır.

\section{Etkinlik 2. Bilimsel bilgi öznel midir?}

Bu etkinlikte, öğretmen adayları bilimsel bilginin öznel olup olmadığı hakkında iddialar oluşturarak bilimsel bilginin niçin öznel olduğunu tecrübe etmeleri hedeflenmiştir. Etkinlikte öğretmen adaylarına iki iddia verilerek (bilimsel bilgi özneldir ve bilimsel bilgi öznel değildir) bunlardan hangisine katıldıkları ve niçin bunu destekledikleri sorularak deliller sunmaları ve akıl yürütme yapmaları istenmiştir. Daha sonra karşıt görüşün iddialarına karşı çürütücüler vermeleri istenmiştir. Etkinlik sonucunda öğretmen adaylarının bilimsel bilginin öznel olduğu iddiasını argümantasyon destekli açık düşündürücü yaklaşım ile öğrenmeleri amaçlanmıştır.

\section{Etkinlik 3. Istanbul'da büyük deprem olacak mı?}

Bu etkinlikte, öğretmen adayları bilimsel bilginin öznel olup olmadığı hakkında iddialar oluşturarak bilimsel bilginin niçin öznel olduğunu tecrübe etmeleri hedeflenmiştir. Bilimsel bilginin öznel olup olmadığını ve bilimsel bilginin sosyal ve kültürel ortamdan etkilenebileceğini anlamaları için öğretmen adaylarına İstanbul'da 2015 yılına kadar deprem olacağı ve olmayacağını savunan iki farklı profesörün raporlarını anlatan iki okuma parçası verilmiştir. Okuma parçalarından birinde isstanbul'da 2015 yılına kadar büyük bir deprem olacağı bilimsel verilerle desteklendiği iddia edilirken diğer okuma parçasında İstanbul'da 2015 yılına kadar deprem olacağını gösteren hiçbir verinin olmadığı iddia edilmektedir. Bu okuma parçası sonucunda argümantasyon destekli açık düşündürücü yaklaşım metodu uygulanarak öğretmen adaylarının bilimsel bilginin sosyal ve kültürel ortamdan etkilenebileceğini ve bilimsel bilginin öznelliğiniöğrenmeleri hedeflenmiştir.

\section{Etkinlik 4. Bilimsel bilgi için deney ve gözlemlerden elde edilmiş kanıtlar gerekir mi?}

Bu etkinlikte, öğretmen adayları bilimsel bilginin deney ve gözlemlere dayalı olup olmadığı hakkında iddialar oluşturarak bilimsel bilginin niçin deney ve gözlemlerden elde edilmiş kanıtlara ihtiyaç duyduğunu tecrübe etmeleri hedeflenmiştir. Etkinlikte öğretmen adaylarına iki iddia verilerek (Bilimsel bilgi için deney ve gözlemlerden elde edilmiş kanıtlar gerekir ve bilimsel bilgi için deney ve gözlemlerden elde edilmiş kanıt gerekmez) bunlardan hangisine katıldıkları ve niçin bunu destekledikleri sorularak deliller sunmaları ve akıl yürütme yapmaları istenmiştir. Daha sonra karşıt görüşün iddialarına karşı çürütücüler sunmaları istenmiştir. Etkinlik sonucunda öğretmen adaylarının bilimsel bilginin deneye ve gözleme dayalı olduğu iddiasını argümantasyon destekli açık düşündürücü yaklaşım ile öğrenmeleri amaçlanmıştır.

\section{Etkinlik 5. Hileli Izler!}

Bu etkinlik öğretmen adaylarııı bilimsel bir araştırmada gözlem ve çıkarım arasındaki farkı ve bilimin kesin olmayan doğasını kavramalarını amaçlamaktadır. Etkinliğin ilk kısmında, öğretmen adaylarına "bir konu hakkında sahip olunan farklı fikirlerin hepsinin doğru cevabı temsil etmeyeceği" mesajı verilmeye 
çalışılmıştır. Etkinlikte, projektör yardımıyla ekrana değişik şekiller yansıtılmış ve her bir durumda ne olmuş olabileceği, öğrencilere sorularak bunları açıklamaları istenmiştir. Yaptıkları açıklamaları önce çalışma kâğıtlarına yazmaları ve sonra sınıfla paylaşmaları teşvik edilmiştir. Bu resimlerle ilgili öğrencilerin ortaya attığı senaryolar üzerinde odaklanılarak, gözlem ve çıkarım arasındaki farkı kavramaları sağlanmıştır. Yine, aynı veriyle - resim - ilgili olarak farkı çıkarımlarda bulunulmasının mantıklı olduğu fakat yine de yapılan bu çıkarımların veriyi tam olarak açıklamasının mümkün olamayacağı üzerinde durulmuştur. Bu etkinliğin sonunda, aynı verilere dayalı olarak aynı soru hakkında eşit derecede birçok destekli çıkarımın yapılabileceği belirtilmiştir. Bilimle ilgilenen kişilerin, doğal olaylar hakkında sorulan sorulara cevap bulmaya çalışırken benzer çıkarımlarda bulundukları ifade edilmiştir. Bilim insanlarının sordukları sorularla ilgili cevaplarının ellerindeki verilerle tutarlı olmasına rağmen, tek bir cevabın o veriyi yalnız başına açıklayamadığı hususu tartışımışır. Etkinlik boyunca öğretmen adaylarından kendi oluşturdukları iddialara yönelik deliller sunmaları ve iddialarını reddedici ve niteleyicileri sunmaları istenmiştir. Etkinlik sonucunda öğretmen adaylarının argümantasyon destekli açık düşündürücü yaklaşım ile gözlem ve çıkarım arasındaki farkı kavramaları hedeflenmiştir.

\section{Etkinlik 6. Fosiller}

Bu etkinlik öğretmen adaylarının bilimsel bir araştırmada hayal gücü ve yaratıclığın önemini kavramalarını amaçlamaktadır. Etkinliğin ilk kısmında, öğretmen adaylarına bir fosil parçasının resmi verilerek bunun ne tür bir canlıya ait olabileceğini düşünmeleri ve çizmeleri istenmiştir. Daha sonra öğretmen adaylarından kendi düşüncelerini savunan niteleyici ve reddediciler sunmaları istenir. Öğretmen adaylarının bu argümantasyon sonunda öğrencilere tam resim gösterilerek fosilin hangi canlıya ait olduğu sunulur. Öğretmen adaylarından niçin farklı canlıların resmini çizdikleri tartışmasına rehberlik edilerek bilimsel bilgi oluşturulurken aynı verilerden farklı sonuçlara ulaşılabildiğini fark etmeleri sağlanır. Öğretmen adaylarından ilk verilen fosili herkesin kendi hayal gücü ile tamamladığı ve bilim insanlarının da kendileri gibi bilimsel bilgiyi oluştururken hayal gücü ve yaratıcılıklarını kullanıp kullanmadıklarını tartışmaları istenir. Etkinliğin sonucunda öğretmen adaylarının bilimsel bilginin oluşturulmasında bilim insanlarının hayal gücü ve yaratıcılığından etkilendiğini anlamaları hedeflenmiştir.

\section{Etkinlik 7. Yasa ve Teori Arasındaki Ilişki}

Bu etkinlik Öğretmen adaylarının bilimsel bir araştırmada teori ve kanun arasındaki farkı kavramalarını amaçlamaktadır. Öğretmen adaylarına etkinlik başlangıcında iki teori (Teori 1-Teoriler yeni kanıtlarla yeterince desteklendiğinde yasalara dönüşür ve Teori 2-Kanun ve teoriler farklı bilimsel bilgileri temsil ederler ve aralarında hiyerarşik bir sıra yoktur) ve bu teorilerden herhangi birisini destekleyen kanıtlar listesi verilmiştir. Öğretmen adaylarından bu kanıtları kullanarak teorileri tartışmaları istenmiştir. Öğretmen adayları verilen kanıtları kullanarak teorileri kabul etmişler ya da reddetmişlerdir. Bu etkinlik sonucunda Öğretmen adaylarının teori ve yasa arasındaki ilişkiyi anlamaları hedeflenmiştir. Bu etkinliğin devamında öğrencilere değişen bir fizik kanununun tarihsel değişimini açıklayan bir okuma parçası verilerek kanunlarında yeni veriler ışı̆̆ında değişebileceği vurgulanmaya çalışıımıştır.

\section{ADBD Deney Grubuna Uygulanan Etkinlikler}

Bu deney grubunda uygulanan etkinliklerde ise açık düşündürücü yaklaşımla etkinlikler kavratılmaya çalışıımıştır.

\section{Etkinlik 1. Kendiliğinden Oluşum Kuramı}

Bu etkinlikte öğretmen adayları Louis Pasteur'un deneyleri ve öncesinde yapılmış deneyler tarihsel sıralamada verilerek öğrencilere bilimsel bilginin zamanla nasıl değiştiği açık düşündürücü yaklaşımla kavratılmaya çalışıımışı. Daha sonra öğretmen adaylarından bilim insanlarının da diğer deneyleri ve ya teorileri zamanla değiştirip değiştirmedikleri sorularak öğretmen adaylarından buna benzer örnek vermeleri istenmiştir. Louis Pasteur deneylerinde su ve yeterli besin bulunan ortamda canlıların kendiliğinden oluşmadığını kanıtlamıştır. Çünkü öncesinde yapılan deneylerde kurbağaların yağmur 
suyuyla toprağa geçtiği savunulmaktadır. Louis Pasteur yaptığı deneylerle bu teoriyi çürütmüştür. Bu etkinlik sonucunda öğretmen adayları bilimsel teorilerin yeni bilgiler ve deneyler ışığında değişebileceğini kavramaları hedeflenmiştir.

\section{Etkinlik 2. Bilimsel mi Değil mi?}

Bu etkinlikte öğretmen adaylarına bilimsel olan ve bilimsel olmayan ifadeler verilerek bunları bilimsel olup olmadıklarını belirlemeleri ve nedenlerini açıklamaları istenmiştir. Bu sayede öğretmen adaylarının bilimsel bilginin özelliklerini tartışarak karar vermeleri sağlanır. Bu etkinlik sonucunda bilimin, deneyleri, mantıklı tartışmaları ve kuşkuculuğu kullanarak, kendini diğer araştırma alanlarından ve bilgi parçalarından ayırdığını kavramaları hedeflenmiştir.

\section{Etkinlik 3. Gazete Haberlerini Kullanarak Bilimin Doğasının Öğretilmesi}

Bu etkinlikte öğretmen adaylarına National Geographic News dergisinde yayınlanan lotus çiçeği üzerinde gözlem ve deney yaparak su ve kir tutmayan yüzey kaplama maddesi üreten bilim adamlarının buluşunu anlatan bir okuma parçası verilmiştir. Bu etkinlik aracılığıyla öğretmen adaylarına bilimin doğasının gözlemlenmesi ve yapılan deneylere dayandığı kavratılmaya çalışılmıştır. Bu etkinlik sonucunda öğretmen adaylarının bilimsel bilginin deneylere, mantıklı tartışmalara ve doğada gözlemlere dayandığını kavramaları hedeflenmiştir.

\section{Etkinlik 4. Kavram Çarkı ile Bilim}

Bu etkinlikte öğretmen adaylarına bir kavram çarkı verilerek bilimin ne olduğu sorusu sorulur ve kavram çarkını doldurmaları istenir. Kavram çarkını kendileri dolduracağı için herkesin tanımlamaları farklıdır. Her öğretmen adayı kendi kavram çarkının başlığını ve bilimin özelliklerini kendisi dolduracağı için bilimsel bilginin öznel olduğu, bilimsel bilginin özelliklerini kavram çarkını doldurarak kavramaları sağlanır. Bu etkinlik sonucunda öğretmen adaylarının bilimsel bilginin özelliklerini kavramaları hedeflenmiştir.

\section{Etkinlik 5. Yeni Fosiller}

$\mathrm{Bu}$ etkinlik öğretmen adaylarının bilimsel bir araştırmada hayal gücü ve yaratıcılığın önemini kavramalarını amaçlamaktadır. Bu etkinlikte, öğretmen adaylarına yeni bulunan göz fosili hakkında bir okuma parçası verilmiştir. Bu okuma parçasında gözün hangi canlıya ait olduğu hakkında farklı yorumlar yapılmıştır. Bilim adamları göz fosilinin hangi canlıya ait olduğunu kendi hayal gücü ve yaratıcıklarını kullanarak karar vermişlerdir. Bu etkinlik sonucunda öğretmen adaylarının bilimsel bilginin oluşturulmasında hayal gücü ve yaratıcılığın etkisi olduğunu kavramaları hedeflenmiştir.

\section{Verilerin Analizi}

Öğretmen adaylarının ankete verdiği cevaplar kapsam geçerliğini ve güvenirliğini yükseltmek amacıyla iki uzman tarafından ayrı ayrı dikkatli bir şekilde defalarca okunarak incelenmiş ve "Yok", "Zayıf", "Güçlü" olarak kategorize edilmiştir. Uzmanların yaptıkları kategoriler incelendiğinde kategoriler arasında uyum olduğu görülmüştür. Yapılan analiz sonucunda uzmanlar arasındaki tutarlılık sonuçların \% 75 oranında tutarlı olduğu tespit edilmiştir. Öğrencilerin verdiği cevaplar iddia, veri, kanıt, destekleyici ve çürütücü bileşenlerinin kesin ve yeterli ise güçlü, kesin fakat yeterli değil ise zayıf, kesin ve yeterli değilse veya boş bırakılmışsa yok olarak sınıflandırılmışlardır (Tablo 1). Bu kriterlerin belirlenmesinde ve Tablo 1'in hazırlanmasında literatürdeki yazılı argüman kalitesini değerlendirme için kullanılan "Argümantasyon Seviyeleri" (Osborne, Erduran, \& Simon, 2004) ve diğer çalışmalar (Driver ve diğ., 2000; Zohar \& Nemet, 2002) referans alınarak verilen öğretimde kullanılan Türkçe argümantasyon modelinin (Aktamış ve Hiğde, 2015) yapısına uygunluğa, kavramsal anlamalarına (içeriğin doğruluğu) ve akıl yürütme yapılıp yapılmadığı (Sampson \& Clark, 2008) dikkate alınmıştır. Bu değerlendirme kriterlerine göre çalışmadaki kategorilere ayrılmış cevapların argümantasyon bileşenlerine göre frekans dağılımları Tablo 2'de verilmiştir. Öğretmen adaylarının bilimin doğasına yönelik görüşlerini ifade ederken kullandıkları yazılı argümanlarındaki değişimi göstermek için uygulama öncesi ve sonrası olarak 
ayrı ayrı frekans dağılımları verilmiştir. Tablo 2 ve Tablo 4'teki frekans dağılımları çalışmanın nicel kısmını oluştururken, alıntılarla bu frekans dağılımının desteklenmesi nitel kısmını oluşturmaktadır. Nitel ve nicel olarak sunulan bulgular aracılığıyla destekleyici bulgulara yer verilmiştir.

Tablo 1.

Değerlendirme Kriterleri

\begin{tabular}{|c|c|c|c|c|}
\hline \multicolumn{2}{|l|}{ Bileşen } & 0 (yok) & 1 (zayıf) & 2 (güçlü) \\
\hline \multicolumn{2}{|c|}{$\begin{array}{l}\text { İddia } \\
\text { Bir iddia veya sonuç orijinal soruyu } \\
\text { cevaplar }\end{array}$} & $\begin{array}{l}\text { Bir iddia yok veya } \\
\text { kesin olmayan } \\
\text { iddia }\end{array}$ & $\begin{array}{l}\text { Kesin fakat } \\
\text { tamamlanmamış } \\
\text { iddia }\end{array}$ & Kesin ve tam bir iddia \\
\hline \multirow{2}{*}{$\begin{array}{l}\text { Kanıt Bilimsel veri } \\
\text { iddiayı destekler; } \\
\text { verinin iddiayı } \\
\text { desteklemek için } \\
\text { yeterli ve uygun } \\
\text { olmasına ihtiyaç } \\
\text { vardır. }\end{array}$} & $\begin{array}{l}\text { a. Veri } \\
\text { İddiayı } \\
\text { desteklemek için } \\
\text { içerilen veri }\end{array}$ & $\begin{array}{l}\text { Yanlış ya da hiç } \\
\text { verilmemiş }\end{array}$ & $\begin{array}{l}\text { Günlük } \\
\text { yaşamdaki } \\
\text { deneyimlerinden } \\
\text { sunulan veri }\end{array}$ & $\begin{array}{l}\text { Karşılaştırma yaparak } \\
\text { veriyi sağlamış. } \\
\text { Deneysel ve bilimsel } \\
\text { verilerden yararlanmış }\end{array}$ \\
\hline & $\begin{array}{l}\text { b. Akıl Yürütme } \\
\text { Veri ile iddiayı } \\
\text { birbirine } \\
\text { bağlayan ifade }\end{array}$ & $\begin{array}{l}\text { Yanlış ya da hiç } \\
\text { verilmemiş }\end{array}$ & $\begin{array}{l}\text { Yetersiz akıl } \\
\text { yürütme }\end{array}$ & $\begin{array}{l}\text { Bilimsel veri ile } \\
\text { desteklenmiş yeterli } \\
\text { akıl yürütme }\end{array}$ \\
\hline \multicolumn{2}{|c|}{$\begin{array}{l}\text { Destekleyici } \\
\text { Destekleyicinin kavramsal kalitesi }\end{array}$} & $\begin{array}{l}\text { Destekleyici yok - } \\
\text { yanlış ya da hiç } \\
\text { verilmemiş }\end{array}$ & $\begin{array}{l}\text { Bir tane } \\
\text { destekleyici var }\end{array}$ & $\begin{array}{l}\text { Birden fazla } \\
\text { destekleyici var }\end{array}$ \\
\hline \multicolumn{2}{|c|}{$\begin{array}{l}\text { Çürütücüler } \\
\text { Karşıt iddiaya yönelik verilen } \\
\text { açıklamalar }\end{array}$} & $\begin{array}{l}\text { Çürütücü yok- } \\
\text { yanlış ya da hiç } \\
\text { verilmemiş }\end{array}$ & $\begin{array}{l}\text { Bir tane } \\
\text { çürütücü var }\end{array}$ & $\begin{array}{l}\text { Birden fazla çürütücü } \\
\text { var }\end{array}$ \\
\hline
\end{tabular}

\section{Bulgular}

Argümantasyon destekli açık düşündürücü etkinliklerle ve sadece açık düşündürücü etkinliklerle desteklenen bilimin doğası ve bilim tarihi dersinden önce ve sonrası olarak ADADBD ve ADBD grubundaki öğrencilerin VNOS-C anketine verdikleri cevapların argümantasyon bileşenlerine göre analizinin frekans dağılımları aşağıda verilmiştir. ADADBD grubunun frekans dağılımları Tablo 2'de verilirken, ADBD grubunun dağılımları Tablo 4'te verilmiştir.

\section{a) ADADBD Grubu Bulguları}

Argümantasyon destekli açık düşündürücü etkinliklerle desteklenen bilimin doğası ve tarihi dersinden önce ve sonrası olarak katılımcıların VNOS-C anketine verdikleri cevapların frekans dağılımları aşağıda verilmiştir (Tablo 2). VNOS-C anketindeki 2. soru olan “Deney nedir?" deneyin tanımı ile ilgili soru analize dâhil edilmemiştir. Çünkü bu soru bilgi sorusu olduğu için öğrencilerin argüman kurmaları ve akıl yürütme yapmalarına uygun bir soru değildir. 
Tablo 2.

Öğretmen adaylarının ADADBD dersi öncesi ve sonrası VNOS-C sonuçlarının frekans dağılımları

Bileşenler

Zamanlama

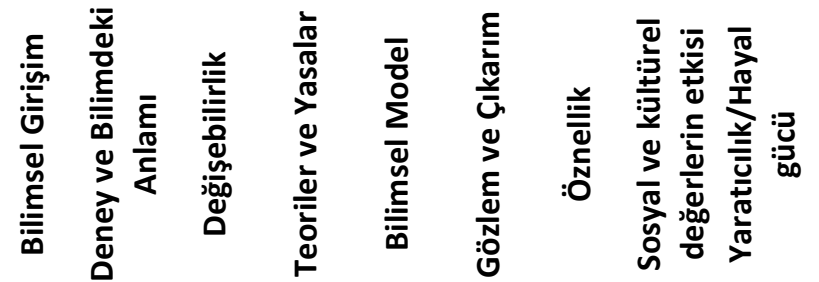

\begin{tabular}{|c|c|c|c|c|c|c|c|c|c|c|c|}
\hline \multirow{6}{*}{ İddia } & \multirow{3}{*}{ Uygulama öncesi } & Yok & 17 & 5 & 2 & 7 & 6 & 8 & 17 & 8 & 4 \\
\hline & & Zayıf & 9 & 17 & 17 & 18 & 21 & 16 & 12 & 17 & 18 \\
\hline & & Güçlü & 4 & 8 & 11 & 5 & 3 & 6 & 1 & 5 & 8 \\
\hline & \multirow{3}{*}{ Uygulama sonrası } & Yok & 6 & 1 & 2 & 0 & 5 & 4 & 0 & 1 & 0 \\
\hline & & Zayıf & 5 & 3 & 4 & 11 & 9 & 12 & 10 & 3 & 6 \\
\hline & & Güçlü & 19 & 26 & 24 & 19 & 16 & 14 & 20 & 26 & 24 \\
\hline \multirow{6}{*}{ Akıl Yürütme } & \multirow{3}{*}{ Uygulama öncesi } & Yok & 24 & 16 & 10 & 19 & 20 & 16 & 25 & 14 & 18 \\
\hline & & Zayıf & 6 & 10 & 19 & 10 & 8 & 14 & 4 & 16 & 12 \\
\hline & & Güçlü & 0 & 4 & 1 & 1 & 2 & 0 & 1 & 0 & 0 \\
\hline & \multirow{3}{*}{ Uygulama sonrası } & Yok & 7 & 1 & 3 & 5 & 7 & 7 & 6 & 2 & 5 \\
\hline & & Zayıf & 9 & 8 & 10 & 10 & 8 & 10 & 8 & 6 & 6 \\
\hline & & Güçlü & 14 & 21 & 17 & 15 & 15 & 13 & 16 & 22 & 19 \\
\hline \multirow{6}{*}{ Veri } & \multirow{3}{*}{ Uygulama öncesi } & Yok & 27 & 22 & 15 & 19 & 17 & 18 & 26 & 17 & 22 \\
\hline & & Zayıf & 3 & 4 & 13 & 10 & 11 & 12 & 3 & 13 & 7 \\
\hline & & Güçlü & 0 & 4 & 2 & 1 & 2 & 0 & 1 & 0 & 1 \\
\hline & \multirow{3}{*}{ Uygulama sonrası } & Yok & 16 & 9 & 12 & 12 & 12 & 7 & 13 & 5 & 7 \\
\hline & & Zayıf & 6 & 7 & 11 & 7 & 5 & 13 & 9 & 8 & 7 \\
\hline & & Güçlü & 8 & 14 & 7 & 11 & 13 & 10 & 8 & 17 & 16 \\
\hline \multirow{6}{*}{ Destekleyici } & \multirow{3}{*}{ Uygulama öncesi } & Yok & 30 & 29 & 30 & 30 & 28 & 30 & 30 & 29 & 29 \\
\hline & & Zayıf & 0 & 0 & 0 & 0 & 2 & 0 & 0 & 1 & 0 \\
\hline & & Güçlü & 0 & 1 & 0 & 0 & 0 & 0 & 0 & 0 & 1 \\
\hline & \multirow{3}{*}{ Uygulama sonrası } & Yok & 30 & 24 & 26 & 25 & 24 & 26 & 27 & 20 & 25 \\
\hline & & Zayıf & 0 & 0 & 1 & 1 & 2 & 2 & 1 & 4 & 1 \\
\hline & & Güçlü & 0 & 6 & 3 & 4 & 4 & 2 & 2 & 6 & 4 \\
\hline \multirow{6}{*}{ Çürütücüler } & \multirow{3}{*}{ Uygulama öncesi } & Yok & 30 & 30 & 30 & 30 & 30 & 30 & 30 & 30 & 30 \\
\hline & & Zayıf & 0 & 0 & 0 & 0 & 0 & 0 & 0 & 0 & 0 \\
\hline & & Güçlü & 0 & 0 & 0 & 0 & 0 & 0 & 0 & 0 & 0 \\
\hline & \multirow{3}{*}{ Uygulama sonrası } & Yok & 30 & 30 & 30 & 30 & 30 & 30 & 30 & 30 & 30 \\
\hline & & Zayıf & 0 & 0 & 0 & 0 & 0 & 0 & 0 & 0 & 0 \\
\hline & & Güçlü & 0 & 0 & 0 & 0 & 0 & 0 & 0 & 0 & 0 \\
\hline
\end{tabular}

Tablo 2 incelendiğinde uygulama öncesinde öğretmen adaylarının büyük çoğunluğunun zayıf argüman kurabildikleri görülürken, uygulama sonrasında güçlü argümanlar kurabildikleri görülmektedir. Akıl yürütme bileşeni dikkate alındığında öğretmen adaylarının çoğunluğunun akıl yürütme sağlamada başarısız oldukları ancak uygulama sonrasında katılımcıların yarısından fazlasının güçlü akıl yürütmeler sağlayabildiği belirlenmiştir. Öğretmen adaylarının veri sağlamada uygulama öncesine göre çok fazla gelişim gösteremedikleri ancak uygulama sonrasında bilimsel bilginin sosyal ve kültürel değerlerden etkilenmesi, hayal gücü ve yaratıcılığın bilimsel bilginin oluşmasındaki rolüne yönelik sorulara veri sağlamada öğretmen adaylarının yarısından fazlasının güçlü veriler sağlayabildiği belirlenmiştir. Akıl 
yürütme ve veri bileşenleri dikkate alındığında öğretmen adaylarının çoğunluğunun kanıt sağlamada başarısız oldukları ancak uygulama sonrasında katılımcıların yarısından fazlasının güçlü kanıtlar sağlayabildiği görülmektedir. Destekleyici sağlamada ise öğretmen adaylarının çok azının gelişim gösterdiği bulunmuştur. Öğretmen adaylarının çürütme basamağında ise hiç gelişim göstermedikleri bulunmuştur. Bu frekans verilerini desteklemek için aşağıda her bir anket sorusuna yönelik alıntılar yapılarak uygulama öncesi ve sonrası olarak ayrı başlıklar altında verilmiştir.

Öğretmen adaylarına ADADBD eğitimi öncesinde ve sonrasında uygulanan bilimin doğası görüşler anketine ilişkin verdikleri cevaplardan dikkat çeken alıntılar tablo 3 'te verilmiştir. Öğretmen adaylarının ön uygulamada bilimi diğer araştırma alanlarından farklı kılan nedir sorusuna yönelik bilimin daha çok deneye dayalı olması, kanıtlanabilir olması, nesnel olması ve akla ve mantığa yatkın olması gibi cevaplar verilmiştir. Katılımcıların çoğunluğu bilimin gelişmesi için deneylere gerek olduğunu düşünmektedir. Bu iddialarını da bilimin gözlenebilirliği, kanıtlanabilirliği, denenebilirliği, gelişimi ve değişimi için deneylere intiyaç duyulmasıyla desteklemişlerdir. Öğretmen adaylarının büyük bir kısmı bilimsel teorilerin zamanla değişeceğini düşünmektedir. Bu iddialarını da bilimsel bilginin zamanın getirdiği gelişmeler ile çürütülebileceği ve teorinin tanım olarak kesin olmadığı ile desteklemişlerdir. Eğer kesin olsaydı yasaya dönüşeceğiyle ilgili kavram yanılgılarının olduğu bulunmuştur. Öğretmen adaylarının büyük bir kısmı teori ve yasa arasında fark olduğunu ifade etmektedir. Aynı zamanda öğretmen adaylarının büyük çoğunluğunun bilimsel teorilerin zamanla yasaya dönüşeceğine dair kavram yanılgısına sahip oldukları görülmüştür. Öğretmen adayları teorilerin kesin olmadığı kanunların ise kesin bir bilgi olduğunu bu yüzden kanunların çürütülemeyeceğini teorilerin ise zamanla çürütüleceğini düşünmektedirler. Öğretmen adayları atom hakkında bilim insanlarının nasıl özel bilgiler kullandıkları ve atomun yapısı hakkında nasıl bu kadar emin olduklarına ilişkin soruya ise deneyler ve kullanılan gelişmiş aletler aracılığıyla ve uzun zaman zarfında gelişen teoriler sayesinde atomun yapısı hakkında emin olabildiklerini ifade etmişlerdir. Öğretmen adayları bir türün ne olduğuyla ilgili özellikler hakkında nasıl emin olduklarıyla ilgili soruya ise dış görünüş, genler, kromozom sayıları, neslin devamı sağlayıp sağlamadığı ve bezelyelerde yapılan deneyleri örnek göstererek bilim insanlarının bir tür hakkında nasıl emin olduklarını desteklemeye çalışmışlardır. Öğretmen adayları bilim insanlarının aynı sonuçlara ve aynı verilere bakarak farklı sonuçlara nasıl ulaştığına ilişkin soruya genellikle cevap verememişler veya olayın birden çok nedeni olabileceğini ifade etmişlerdir. Öğretmen adaylarının çoğunluğu bilimin evrensel olup olmadığıyla ilgili bilimin evrensel olduğunu iddia etmektedirler. Çok az sayıda öğretmen adayı da bilimin kişisel değerlerden ve toplumun değerlerinden etkilenebileceğini iddia etmiştir. Öğretmen adayları bilimde hayal gücü ve yaratıcılığın etkin rol oynadığını ifade etmektedirler. Hayal gücü ve yaratıclığın hemen hemen her aşamada etkin rol oynadığını iddia etmişlerdir.

Öğretmen adayları uygulama sonrasındaki cevaplarında bilimi diğer araştırma alanlarından farklı kılan özelliklerin bilimin din, felsefe gibi sözel alanlara göre daha nesnel olması, kanıtlanabilir olması ve bilimsel süreç becerileriyle sınanması olduğunu iddia etmişlerdir. Öğretmen adayları bilimin gelişmesi, doğrulanması ve gerçekleştirilmesi için deneye ihtiyaç duyduğunu ifade etmişlerdir. Büyük çoğunluğu da bilimsel deneylerden ve buluşlardan örnekler vererek bilimsel bilginin oluşmasında deneyin önemini desteklemeye çalışıı̧lardır. Öğretmen adayları bilimsel teorilerin zamanla değişebileceğine dair iddialarda bulunmuştur. Ayrıca uygulama öncesine göre öğretmen adaylarının daha çok kanıt, veri ve destekleyici kullanmaya ve uygulamada karşılaştıkları bilim tarihi ve bilimsel teorilerden örnekler vermeye çalıştıkları bulunmuştur. Öğretmen adayları bilimsel yasa ve teori arasındaki farkı uygulamadan önce olduğu gibi hala aralarında hiyerarşik bir ilişki olduğunu ve yasanın değiştirilemez olduğunu ifade etmektedirler. Ancak uygulamadan önceki cevaplarına göre uygulama sonrası cevaplarında iddiaları yanlış olsa da iddialarını bilimsel teoriler, yasalar ve bilim tarihinden örnekler ile desteklemeye çalışmaktadırlar. Öğretmen adayları uzun yıllardan bu yana süregelen farklı görüşleri, birçok deney sonuçlarını, teknolojinin gelişmesiyle ve yeni deneylerin yapılmasıyla kısacası bilimsel bilginin birikimiyle atomun yapısı hakkında emin olabildikleri iddiasında bulunmuşlardır. Uygulama öncesine göre öğretmen adayları bilimsel teorileri ve gelişimini daha çok iddialarını desteklemek ve kanıt sağlamak için kullanmışlardır. Öğretmen adayları bilim insanlarının türler hakkında araştırma yaparken türleri 
gözlemlediklerini, türlerin benzeyen özelliklerini kullandıklarını ve bunlara dayalı çıkarımlar ile türler hakkında emin olabildiklerini ifade etmişlerdir. Ayrıca türlerin çiftleştiklerinde verimli döl verip verememe özelliklerini dikkate aldıklarını söylemişlerdir. Uygulama öncesine göre öğretmen adaylarının daha fazla bilimsel örnek ve bilgiye yer vererek iddialarını desteklemeye çalıştıkları ve kanıt sağlamaya çalıştıkları bulunmuştur. Öğretmen adayları bilim insanlarının aynı verileri kullanarak farklı sonuçlara ulaşma durumlarını bilim insanlarının kendi kişisel farklı görüşlere ve varsayımlara sahip olmasıyla açıklamaya çalışmışlardır. Bu iddialarını da farklı bilimsel teorileri kullanarak desteklemeye çalışmışlardır. Öğretmen adaylarının çoğunluğu bilimsel bilginin nesnel olduğunu, bilimin sosyal ve kültürel değerlerden ve içinde bulunduğu toplumun felsefi ve dini değerlerinden ve ekonomik koşullarından etkilendiğini ifade etmişlerdir. Uygulama öncesine göre katılımcıların hem görüşlerinde değişme olmuş hem de iddialarını bilim tarihinden örnekler ve teorileri vererek desteklemeye ve kanıt sağlamaya çalıştıkları görülmüştür. Bilimin hayal gücü ve yaratıcılığa dayandığını iddia etmişlerdir. Uygulama öncesine göre öğretmen adaylarının daha fazla güçlü iddialar ile hayal gücü ve yaratıcılığın bilimsel bilginin oluşmasındaki önemine dikkat çekmişlerdir. Bu iddialarını Newton, Arşimet, Einstein, Mendel ve Thomson gibi bilim insanlarının buluşları ve icatlarını örnek vererek desteklemeye ve kanıtlamaya çalışmışlardır. Aşağıda Tablo 3'de cevapları dikkat çeken ve anlaşıır olan öğrencilerin uygulama öncesi ve sonrası görüşleri verilmiştir.

\section{Tablo3.}

ADADBD Grubu Öğrencilerinin Uygulama Öncesi ve Sonrası Görüşlerinden Alıntılar

\section{Uygulama öncesi görüşler}

ÖP: "Bilim doğayı ve doğanın işleyişini inceler. Ayrıca bu işleyişine neden olan durumları açıklar. (kanun, teori, ...vb.) işte bilimi diğer araştırma alanlarından farklı kılan durum açıklamalar

$\stackrel{\xi}{\underline{m}}$ yaparken neden-sonuç çerçevesinde ve eğer kanun olmuş bir durum varsa bunu kanıtlarla deneylerle açıklamış olmasıdır."

ÖZ: "Bilim evreni çevreyi, doğayı tanımak 言 demektir. Bilimi diğer alanlardan farklı yapan ise deneylerle kanıtlanabilir olmasıdır."

ÖU: "Bilim var olduktan sonra doğada gerçekleşen olayları inceler. Nesneldir. Akla ve mantığa dayanır. Din ve felsefe varoluş sebebini inceler. Özneldir."

\section{Uygulama sonrası görüşler}

ÖA: "Bilim doğayı canlıları cansız varlıkları varoluşu ve yaşanılan çevreyi araştıran kavramlar tanımlar yaratan ilgi alanlarıdır. Din, felsefe gibi sözel alanlar nesnelden daha çok öznel boyuttadır. Kişinin fikirlerine deneyimlerine geçmiş yaşantısına göre değişebilir. Fizik, kimya, biyoloji gibi alanlar bilimsel süreç becerileri ile sınanırlar. Nesnel boyuta geçerler."

ÖS: "Bilim insanların merakları sonucu, yaptıkları gözlemlerle, deneylerle, buluşlarıyla bir bilgiye veya icada ulaşma sürecine bilim denir. Bilimi diğer araştırma alanlarından ayıran özellik denenebilir ve kanıtlanabilir olmasıdır. Belli akıl ve mantık çerçevesinde kesin bilgiye ulaşmak istenir." 
ÖZ: “Evet. Çünkü bilimsel bilginin gözlemlenebilir veya kanıtlanabilir olması gerekmektedir. Yapılan deneyler farklı bilgiler ortaya çıkarttığı için deneylere intiyaç vardır. Yüzeyin pürüzle olması hareketi zorlaştırır."

ÖB: "Evet vardır. Örneğin ilk atom modelinde verilen bilgiler yetersiz kalmış ve bilim adamlarının araştırmaları doğrultusunda daha gelişmiş sonuçlar ortaya çıkmıştır."

ÖG: "Evet vardır. Deney yoluyla bilgiler ispatlanmış olur. Doğru ve yanlış bilgiler bu şekilde birbirinden ayrılır. Bu şekilde de bilimsel bilgi gelişir."

ÖD: "Evet deneylere ihtiyaç vardır. Bilimsel bilgi desteklenen bilgidir ve bu çoğu zaman deney yoluyla olur. Mesela atom teorisi deneyler ve gözlemlerle elde edilen bilimsel bilgidir."

ÖN: "Gereklidir. Bilgiye varmanın en güzel yolu deneyerek gözleyerek varılmasıdır. Mesela öğrenciler suyun kaldırma kuvvetini öğrenmek istiyor. Onlara en basit bir düzenekle kabın içine bir miktar su koyarak üzerine birkaç hafif nesneler bırakarak gösterebiliriz."

ÖG: "Evet, bilimsel bir teori zamanla değişebilir. Çünkü o zamanın şartlarına göre oluşturulan teorinin üzerinden uzun bir süre geçtikten sonra teori çürütülebilir."

ÖM: “Çünkü teoriyi bulduğumuzda direk yasa haline gelmiyor birçok deney yapilıyor teoriler üzerinden. En son olarak doğru teori olan teori kanunlaşıyor. Bu yüzden sürekli farklı teoriler yazılabilir, teoriler değişebilir."

ÖGA: "Evet değişebilir. Örneğin atom modellerine baktığımızda Dalton'dan başlamış. Bohr'a kadar yanılgılar fark edilmiş ve değişime uğramıştır.

Teorileri hiçbir zaman kesin gözüyle bakılmamıştır.

Değişmemesi için kanun olması gerekmektedir. Teoriler değişebilir."

ÖA: "Teoriler değişebilir. Kanunlar değişmez. Newton hareket kanunları her yerde aynı kabul görmesine rağmen evrim teorisi herkes kabul edilmez. Teorilerin düzenlenmesi incelemesi ile onlara katkılar sağlar. Bir bilim insanı kendinden önceki bir teoriyi ele alıp eksiklerini giderir yeni bir teori sunar."

ÖMA: "Değişebilir. Çünkü atom teorilerinde her bilim adamı en başından beri birbirinden etkilenerek teorilerini çürütmüştür. illk atom teorisinde yörünge kavramı yokken diğer bilim adamları yörüngeyi bulmuştur. Teorileri öğrenmemiz gerekir. Çünkü sonraki teoriler ilk teorilerden yola çıkarak oluşmuştur."
ÖP: “Evet vardır. Çünkü deneyler yapılan gözlemleri doğrulamak için yapılan bilimsel adımlardır. Bilimsel sürecin üçüncü adımı deney yapmaktır. Örneğin, Faraday eğer deney yapmasaydı manyetik alanla elektrik arasındaki ilişkiyi gösteren kanunlara ulaşamazdı."

ÖZ: "Günlük yaşantımızda kullandığımız pek çok şeyi örnek verebiliriz. Sarkaçlı saatler, araba tekerleri, asit ve baz tepkimesi gibi. Tüm bunları bilimsel bilginin deneylere uygulanmasıyla öğrenebiliriz."

ÖH: "Evet, çünkü bir iddiayı kanıtlarıyla ve destekleyicileriyle araştırma yapabilmesi için deneylere intiyaç vardır. Deneylerle yapılan bilimsel bilgiyi kanıtlamak ve savunmak daha kolay olur. Örneğin, Newton'un yerçekimi yasasında yaptığı deneyler."

ÖBA: "Evet vardır. Bilimsel bilgi deneyler yaparak gelişir. Örneğin, sıvıların kaldırma kuvveti deneyler yaparak gelişmiştir. Newton'un yerçekimi yasası örnek verilebilir. Deneyler yaparak bilimsel bilginin kanıtları savunulabilir."

ÖM: "Evet. Çünkü bilimsel bilgi kanıt ister bunun için olayın kanıtlanması gerekir. Örnek olarak yerçekimi kuvveti, deney ve gözlem olarak Newton'un kafasına elma düşmesi."

ÖM: "Bilimsel teoriler değişebilir. Teoriler yaşanılan zamandan etkilenebilir. Örneğin o dönemim kültür yapısı bile etkilidir. Kullanabilecekleri araç-gereç kısıtıılığı teorilerin değişebileceğini gösterir. Örneğin atom teorileri Dalton-Thomson-Rutherford atom teorileri zamanla gelişmiştir. Çünkü kullandıkları araçgereçler etkilidir. Bilim birikimli ilerler. Her bir teori diğeri için zemin oluşturmuştur. Teoriler beraberinde merak duygusunu da getirir."

ÖBB: "Bilimsel teoriler değişir. Atom teorisi ve evrim teorisi bilimin ilerlemesi ve teknolojinin gelişmesiyle üzerine yeni bilgiler ekleniyor. Zaman ilerledikçe yeni kanıtlar ortaya çıkıyor. Bu yüzden bilimsel teoriler değişebilir."

ÖH: "Teoriler değişiyor. Örneğin, atom ve evrim teorisine her gün yeni fikirler ortaya çıkarak teorileri değiştiriyor. Şu anki evrim teorisi ucu açık bir teoridir. Ucu açık olduğu için yeni araştırmalara açıktır. Bu yeni araştırmalarda teoriye katılarak teoriyi değiştiriyor." 
Ös: "Kesinlikle vardır. Bilimsel teori deney yoluyla ispatlanabilir de yanlış da olabilir. Ama kanun kesinlikle değişmez. Darwin teorisi kesin değildir." ÖU: "Fark vardır. Teori değiştirilebilir olmasına rağmen yasa değiştirilemez. Örneğin evrim teorisine karşın farklı düşünceler ortaya çıkmasına rağmen Newton yasasında böyle karşıt düşünceler ortaya atılmamıştır. Sadece destekleyici olmuştur. O yüzden kabul edilmiş ve kesindir."

ÖB: "Bilimsel bir teori çürütülebilir fakat yasa çürütülemez. Ohm yasasını ve evrim teorisini örnek olarak verebiliriz."

ÖBA: "Birçok deney yaptıktan sonra böyle bir yargıya varıyorlar. Gelişmiş aletlerle araştırma yaptıktan sonra bu bilgileri ortaya çıkarıyorlar."

ÖD: "Bilim insanlarının atom ve parçacıklarını keşfetmesi hızlı bir şekilde olmamıştır. Bunu çeşitli (Bohr, Dalton, Thomson) atom modellerinden de anlayabileceğimiz gibi kademeli deneme-yanılma yöntemiyle gerçekleşmiştir. Örneğin milikan deneyi bize elektronların da bir kütlesi olduğunu göstermiştir. Her bir sonraki bilim insanı bu bilgilere dikkat ederek bu bilgiler ışığında yeni teoriler üretmiştir."

ÖA: "O alanda yapılan deneyler sonucunda elde edilen verileri kullanılır. Ancak atomun bile daha küçük yapılardan (kuarklar) meydana geldiği ortaya
ÖA: "Teori geçerliliğini kaybedebilir oysaki yasa değişmez özelliktedir. Thomson atom modeli değişip gelişerek Bohr'a dönüşsmüştür. Evrim teorisi herkesçe kabul edilmez. Yer çekimi herkesçe kabul edilir."

ÖMA: "Bilimsel bir teori değişebilir. Ama bilimsel bir yasa değişemez. Örneğin, ışık hızının hiçbir referans sisteminde değişmeyeceği yasalaşmıştır. Ancak "esir" kavramı hala bir teoridir. Çünkü var olup olmadığı konusunda hala şüpheler vardır."

ÖMA: "Bilim insanları atomun yapısını farklı şekillerde ifade etmiştir. Uzun yıllarca atom yapısı hakkında farklı görüşler ortaya atılmıştır. Örneğin, Thomson, dalton, bohr atom modeli. Günümüzde teknoloji ilerledikçe atomun yapısı kesinleşmiştir. Örneğin, atomu üzümlü keke benzeten Thomson bir kekteki üzümleri elektron olarak düşünmüştür."

ÖR: "Bilim insanları birçok deneyler yaparak atom hakkında emin konuşmaktadırlar. Atomun bu halini söyleyebilmek için birçok teori oluşmuş deneyler yapılmış zamanla bilimin gelişmesiyle en kapsamlı elde edilen bilgi elde edilmiştir. Bilim insanları atomun neye benzediğine karar verirken önceki bilim adamlarının atom üzerinde yapılan deneyleri bilgileri araştırmıştır ve yapmışlardır. Bunun sonucunda yanlış yerler düzeltilerek atom yapısı değiştirilmiştir. Atom önceden üzümlü keke vb. durumlara benzetilmiştir. Bilimle birlikte bu düşünce değişmiş bugünkü durum oluşmuştur."

ÖH: "Tabi ki bu bilimsel düşünceler hakkında birçok deneyler yapmışlardır. Emin olabilmeleri içinde birbirlerinden kendilerinden önceki bilim adamlarından çok etkilenmişlerdir. Örneğin, birçok atom modelleri vardır. Thomson, Bohr, Dalton, modern atom teorisi. Sırasıyla hepsi araştırmalar yapmışlar ve kendilerinden önceki bilim adamlarının çalışmalarını da katarak son haline getirilmiştir. Üzümlü kek modeline benzetmeleri gibi..."

ÖS: "Atom ilk olarak mantar tıpa içindeki baloncuklar olarak nitelendirildi. Daha sonraları mikroskobun icadı ile üzümlü kek, Dalton atom modeli, Thomson atom modeli, Rutherford atom modelleri geliştirilmiştir. Zaman geçtikçe bilginin yeterliliği açıklanamayan noktalar saptanır. Gelişen teknolojik malzemeler sayesinde kendilerinden emin olurlar." 
ÖBA: “Benzer özelliklerinden yola çıkılır. Dış görünüş, genleri, kromozom sayıları gibi bilgilere bakılır."

ÖAA: "Tür olduğuna karar verebilmek için aralarında çiftleştiklerinde verimli döller

E alınabiliyor ve neslin devamını sağlanıyorsa türdür.

Bu özelliklerinden yararlanarak böyle bir tür tanımı ت. yapılmıştır."

§ ÖP: "Tabii ki yapılan çalışmalar doğrultusunda ⿷ bulunan kanunlara, yasalara göre yani bunlar $\stackrel{\mathbb{N}}{:}$ deliller oluyor. Mesela bezelyelerle çaprazlama G yöntemiyle deneyler yapılıyor. Sonra farklı bitkilerle yapılıp sonuçlar karşılaştırılıyor ve belli bir türün özellikleri ortaya çıkıyor."

ÖAA: "Bir olayın birden çok nedeni olabilir. Eğer bir yasaya ulaşmak için teorilerden yola çıkılarak ulaşılabilir. İki farklı teorinin olması birden çok nedeni ve hipotezi beraberinde getirir."
ÖBB: "Bilim insanları türler arasındaki benzerliklerden yola çıkmışlardır. Canlıların kuyruklu olup olmadığına ya da kanatlı, tüylü, suda ya da karada yaşayıp yaşamadığına bakarak birbirleriyle kıyaslayarak hangi türe ait olduğunu belirleyebilirler. Örneğin, kıyaslayarak hangi türe ait olduğunu belirleyebilirler. Örneğin, kedigiller, yırtıcılar, tek çenekli bitkiler çift çenekli bitkiler bu gibi canlılar farklı özelliklerine göre türlerine ayrılabilir."

ÖS: "Emin olmak için deneyler de gözlemlerle emin olmuşlardır. Laboratuvar ortamlarında yapılan döllenmeler veya doğal ortamda yapılan gözlemler sonucunda bu yargıya ulaşılır. Örneğin, at ve eşek çiftleşmesi ile verimli döller elde edilmez. Ama kurt ile köpek arasındaki çiftleşme ile verimli döl elde edilir. Uzun süreli gözlemler ve takipler sonucunda özel delillere ulaşılıyor."

ÖA: "Farklı düşüncelere sahip olup da aynı verilere ulaşmalarına rağmen farklı yargılar oluşturmalarının sebebi farklı varsayımlar üzerinde araştırmalarını yapmalarıdır. Bilim adamı olmanın özelliklerinden biri de inanmalarıdır. Farklı bilim adamları farklı varsayımlara inanırlar ve çalışmalarını bu çerçevede sürdürürler. Bu durum insanın maymundan gelmesi ve yaradılış teorisi arasındaki durum gibidir."

ÖR: "Her bilim adamının kendi kişisel görüşlerini bilimsel bilgiye aktarması gibi bir olay söz konusudur. Kullanılan veriler ve ulaşılan aynı veriler bir şekilde fazla sıcaklık ve yok oluş ile dinozorların kaybolduğunu söylemektedir. Bunun volkan ya da meteor olması bilim insanının düşüncesidir. Bu olay denenemez ve o zamana ait kanıt ya da yaşanmış hikâye anlatımı bulunamaz bu olayın gerçekleşmesi bir şekilde bilim insanlarınca açıklanmaya çalışılmıştır." 
ÖM: “Bilim evrenseldir. Sosyal ve kültürel değerler bilimi etkilemeye çalışsa da evrenseldir. Örneğin; yerçekimi bir kültür için var olup farklı bir kültür için yok olamaz."

ÖT: "Bilim evrenseldir. Çünkü çevre şartlarına göre değişen bir bilim yoktur. Herkesin kabullendiği bir bilim vardır. (evrensel çekim yasası-yani yerçekimi buna örnek)"

ÖR: "Bilim evrenseldir bence çünkü bilimsel olaylar birçok farklı kültür ve toplumdaki bilim adamları tarafından incelenmektedir. Bilimsel olaylar her zaman doğru olduğu ve ispatlarla ifade edildiği için her toplum tarafından kabul edilmektedir."

ÖG: "Bilim içinde bulunduğumuz toplumdan etkilenir. İnsanın içinde olduğu her şey onun yaşayışının etkisindedir. Neyi merak ettiği bile toplum yaşayışına göre değişebilir. Bu da arayışını araştırmayı etkiler. Kutuplarda yaşayan insanlar buzun yapısıyla ilgilenebilir. Buzlardan evler, aletler yapabilir."
ÖZ: "Bilim çevresindeki sosyal ve kültürel değerlerden etkilenir. Çünkü bilim insanları geliştirmek için yaşam şartlarını kolaylaştırmak için yapıldığından dolayı çevreden etkilenir. Örneğin; Kopernik çalışmalarını yaşamının sonlarına doğru yayınlamıştır. Çünkü kilisenin ve çevresinin tepkilerini bilmektedir. Bu nedenle önsözünde yazdığı bilgilerin sadece felsefe olarak doğru olduğunu belirtmiştir. Yani çevrenin tepkisini almak istememiştir. Aynı duruma Galileo'yu verebiliriz."

ÖBB: "Bilim, sosyal ve kültürel değerlerden etkilenir. Çevrenin baskısında kalabilir. Sosyal ve kültürel değerlerle oluşan etkenler bilimi olumlu ya da olumsuz etkileyebilir. Örneğin, 19. yy'de din ve bilim savaş içindeydi. Darwin'in evrim teorisine en büyük tepki dini çevrelerden geliyordu. Burada dinin bilimi etkilendiği sonucuna ulaşırız."

ÖM: "Bilim en baştaki yıllarda aslında sosyal ve kültürel değerlerden etkilenmiştir. Özellikle din konusunda büyük bir etkilenme söz konusudur. Örneğin, Galileo teleskop ile yaptığı gözlemlerde Jüpiter, ay, dünyanın güneş etrafında dönmesi gibi çeşitli yargılarda bulunmuştur. Fakat o zamanlarda kilise bunun kutsal kitap Yeşu'ya aykırı olduğunu söyleyerek 2 kere mahkeme önüne çıkarmıştır."

ÖGA: “Evet kullanıyorlar. Rutherford 'un üzümlü kek modeli, Newton'un yer çekimi bulma aşaması, Pisagor'un eşeğin sırtında bağıntısını bulması örnek verilebilir."

ÖM: "Bilim insanları diğer insanlardan farklı olarak merakları nedeniyle ve yeni bir bilgi yapma istekleriyle hayal gücü ve yaratıcılıklarını kullanarak birçok buluş ortaya koymuştur. Bazen gözlem yapamadıkları durumlarda hayal güçlerini kullanarak nasıl olması gerektiğinden yola çıkarak çalışmalarını sürdürür."
ÖP: "Hayal gücüne dayalıdır. Merak edilen bir sorunun cevabını aslında hipotez kurmadan önce hayal ederler. Planlama ve düzenleme aşamasında yaratıcılıklarını ve hayal güçlerini kullanırlar. Deney düzeneği kurma ve yapılan deney sonucu ortaya çıkan sonuç da aslında yaratıcılıklarını kullanır. Einstein mıknatısta oluşan manyetik alanı hayal gücüyle kafasında yaratmış ve sonuca ulaşmıştır."

ÖBB: "Evet, bilim insanları hayal gücü ve yaratıcıklarını kullanırlar. Böyle olmasa birçok yasa oluşmazdı. Soyut olan bir şeyi kendi akılcılığını, yaratıcılığını ve hayal güçlerini kullanarak deneyler ve araştırmalar yaparak somut bir veriye, gerçeğe dönüştürmüşlerdir. Örneğin, Thomson atom modelinde, üzümlü keki soyut olan atomun yapısını görselleştirerek somut bir bilgiye dönüştürmüştür."

ÖH: "Kullanıyorlar. Her bilim insanı merak ederek hayal gücünü kullanarak çalışmalar yapmıştır. Örneğin, Newton'un bir ağacın altında otururken elmanın kafasına düşmesini merak etmesi gibi, Arşimet'in suyun üzerinde taşın nasıl kalabildiğini merak etmesi gibi. Newton bu merakıyla yer çekim kuvvetini, Arşimet'se suyun kaldırma kuvvetini bulmuştur."

\section{b) ADBD Deney Grubu Bulguları}

Açık düşündürücü etkinliklerle desteklenen bilimin doğası ve öğretimi dersinin öncesi ve sonrası olarak katılımcıların VNOS-C anketine verdikleri cevapların frekans dağılımları aşağıda verilmiştir (Tablo 4). 
Tablo 4.

Öğretmen Adaylarının ADBD Dersi Öncesi ve Sonrası VNOS-C Sonuçlarının Frekans Dağılımları

\begin{tabular}{|c|c|c|c|c|c|c|c|c|c|c|c|}
\hline Bileşenler & Zamanlama & & 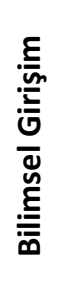 & 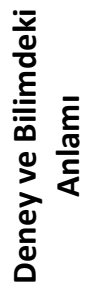 & 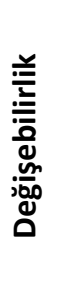 & 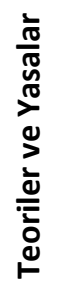 & 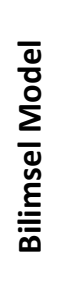 & 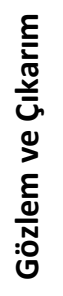 & 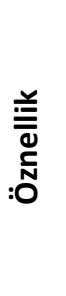 & 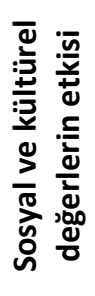 & 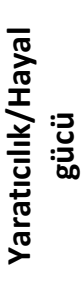 \\
\hline \multirow{6}{*}{ İddia } & \multirow{3}{*}{ Uygulama öncesi } & Yok & 18 & 3 & 10 & 3 & 20 & 22 & 25 & 17 & 19 \\
\hline & & Zayıf & 18 & 31 & 23 & 33 & 17 & 13 & 15 & 19 & 17 \\
\hline & & Güçlü & 4 & 6 & 7 & 4 & 3 & 5 & 0 & 4 & 4 \\
\hline & \multirow{3}{*}{ Uygulama sonrası } & Yok & 12 & 0 & 3 & 2 & 11 & 11 & 16 & 7 & 10 \\
\hline & & Zayıf & 12 & 27 & 21 & 20 & 28 & 25 & 19 & 20 & 19 \\
\hline & & Güçlü & 16 & 13 & 16 & 18 & 1 & 4 & 5 & 13 & 11 \\
\hline \multirow{6}{*}{ Akıl Yürütme } & \multirow{3}{*}{ Uygulama öncesi } & Yok & 36 & 23 & 25 & 34 & 32 & 30 & 38 & 31 & 31 \\
\hline & & Zayıf & 3 & 14 & 13 & 5 & 4 & 9 & 2 & 9 & 9 \\
\hline & & Güçlü & 0 & 3 & 2 & 1 & 4 & 1 & 0 & 0 & 0 \\
\hline & \multirow{3}{*}{ Uygulama sonrası } & Yok & 15 & 2 & 7 & 12 & 22 & 14 & 23 & 14 & 20 \\
\hline & & Zayıf & 23 & 33 & 26 & 20 & 18 & 25 & 17 & 22 & 17 \\
\hline & & Güçlü & 2 & 5 & 7 & 8 & 0 & 1 & 0 & 4 & 3 \\
\hline \multirow{6}{*}{ Veri } & \multirow{3}{*}{ Uygulama öncesi } & Yok & 39 & 35 & 35 & 36 & 35 & 38 & 39 & 34 & 36 \\
\hline & & Zayıf & 1 & 5 & 4 & 2 & 3 & 2 & 1 & 6 & 4 \\
\hline & & Güçlü & 0 & 0 & 1 & 2 & 2 & 0 & 0 & 0 & 0 \\
\hline & \multirow{3}{*}{ Uygulama sonrası } & Yok & 29 & 17 & 19 & 18 & 30 & 34 & 31 & 28 & 28 \\
\hline & & Zayıf & 11 & 22 & 18 & 16 & 10 & 5 & 9 & 11 & 11 \\
\hline & & Güçlü & 0 & 1 & 3 & 6 & 0 & 1 & 0 & 1 & 1 \\
\hline \multirow{6}{*}{ Destekleyici } & \multirow{3}{*}{ Uygulama öncesi } & Yok & 40 & 40 & 40 & 40 & 40 & 40 & 40 & 40 & 40 \\
\hline & & Zayıf & 0 & 0 & 0 & 0 & 0 & 0 & 0 & 0 & 0 \\
\hline & & Güçlü & 0 & 0 & 0 & 0 & 0 & 0 & 0 & 0 & 0 \\
\hline & \multirow{3}{*}{ Uygulama sonrası } & Yok & 40 & 40 & 40 & 40 & 40 & 40 & 40 & 40 & 40 \\
\hline & & Zayıf & 0 & 0 & 0 & 0 & 0 & 0 & 0 & 0 & 0 \\
\hline & & Güçlü & 0 & 0 & 0 & 0 & 0 & 0 & 0 & 0 & 0 \\
\hline \multirow{6}{*}{ Çürütücüler } & \multirow{3}{*}{ Uygulama öncesi } & Yok & 40 & 40 & 40 & 40 & 40 & 40 & 40 & 40 & 40 \\
\hline & & Zayıf & 0 & 0 & 0 & 0 & 0 & 0 & 0 & 0 & 0 \\
\hline & & Güçlü & 0 & 0 & 0 & 0 & 0 & 0 & 0 & 0 & 0 \\
\hline & \multirow{3}{*}{ Uygulama sonrası } & Yok & 40 & 40 & 40 & 40 & 40 & 40 & 40 & 40 & 40 \\
\hline & & Zayıf & 0 & 0 & 0 & 0 & 0 & 0 & 0 & 0 & 0 \\
\hline & & Güçlü & 0 & 0 & 0 & 0 & 0 & 0 & 0 & 0 & 0 \\
\hline
\end{tabular}

Tablo 4 incelendiğinde uygulama öncesinde öğretmen adaylarının büyük çoğunluğunun zayıf argüman kurabildikleri görülürken, uygulama sonrasında güçlü argümanların sayısındaki artışa rağmen zayıf argüman kurabilen katılımcı sayısının hala fazla olduğu görülmektedir. Akıl yürütme bileşeni dikkate alındığında öğretmen adaylarının çoğunluğunun akıl yürütmede başarısız oldukları ancak uygulama sonrasında katılımcıların yarısından fazlasının zayıf akıl yürütmeler yaptığı belirlenmiştir. Öğretmen adaylarının veri sağlamada uygulama öncesine göre çok fazla gelişim gösteremedikleri ancak veri sağlamada öğretmen adaylarının dörtte birinin zayıf veriler sağlayabildiği belirlenmiştir. Akıl yürütme ve veri bileşenleri birlikte değerlendirildiğinde, öğretmen adaylarının çoğunluğunun kanıt sağlamada 
başarısız oldukları ancak uygulama sonrasında katılımcıların yarısından fazlasının zayıf kanıtlar sağlayabildiği belirlenmiştir. Destekleyici sağlama ve çürütme yapmada ise öğretmen adaylarının hiçbirinin gelişim göstermediği bulunmuştur. Bu frekans verilerini desteklemek için aşağıda her bir anket sorusuna yönelik alıntılar yapılarak uygulama öncesi ve sonrası olarak ayrı sütunlar altında verilmiştir.

Öğretmen adaylarına ADBD eğitimi öncesinde ve sonrasında uygulanan bilimin doğası görüşler anketine ilişkin katılımcıların verdikleri cevaplardan dikkat çeken alıntılar Tablo 5 'te verilmiştir. Öğretmen adaylarının ön uygulamada bilimi diğer araştırma alanlarından farklı kılan nedir sorusuna yönelik bilimin daha çok deneye ve gözleme dayalı olması, değişken olması gibi cevaplar verilmiştir. Katılımcıların çoğunluğu bilimin gelişmesi için deneylere gerek olduğunu düşünmektedir. Bu iddialarını da bilimin kanıtlanabilirliği, denenebilirliği, geliş̧imi ve değişimi için deneylere intiyaç duyulmasıyla desteklemişlerdir. Öğretmen adaylarının büyük bir kısmı bilimsel teorilerin zamanla değişeceğini düşünmektedir. Bu iddialarını da bilimsel bilginin zamanın getirdiği teknolojik gelişimler ile değişmesiyle desteklemişlerdir. Bazı olayları tam olarak açıklayamadığı için zamanla değişebileceğini ifade etmişlerdir. Öğretmen adaylarının büyük bir kısmı teori ve yasa arasında fark olduğunu ifade etmektedir. Öğretmen adayları teorilerin kesin olmadığı kanunların ise kesin bir bilgi olduğunu bu yüzden kanunların çürütülemeyeceğini teorilerin ise zamanla çürütüleceğini düşünmektedirler. Öğretmen adayları atom hakkında bilim insanlarının nasıl özel bilgiler kullandıkları ve atomun yapısı hakkında nasıl bu kadar emin olduklarına ilişkin soruya ise zamanla geliştirilen teoriler ve modellerin sonucunda yapılan deneylerle bu bilgileri doğrulayan kanıtlar kullandıklarını ifade etmişlerdir. Öğretmen adayları bir türün ne olduğuyla ilgili özellikler hakkında nasıl emin olduklarıyla ilgili soruya ise canlının genlerini, verdiği yavruları ve yaptıkları deneyleri örnek göstererek bilim insanlarının bir tür hakkında nasıl emin olduklarını desteklemeye çalışmışlardır. Öğretmen adayları bilim insanlarının aynı sonuçlara ve aynı verilere bakarak farklı sonuçlara nasıl ulaştığına ilişkin soruya genellikle cevap verememişler ve cevap veren katılımcılar ise bilim insanın yaşadığı kültürden, çalışma ortamından etkilendiğini ifade etmişlerdir. Öğretmen adaylarının çoğunluğu bilimin evrensel olup olmadığıyla ilgili bilimin evrensel olduğunu iddia etmektedirler. Bunun yanında az da olsa bilimin toplumun ve kültürün değerlerinden etkilendiğini ifade etmişlerdir. Öğretmen adayları bilimde hayal gücü ve yaratıcılığın hemen hemen her aşamada etkin rol oynadığını iddia etmişlerdir.

Öğretmen adayları uygulama sonrasındaki cevaplarında bilimi diğer araştırma alanlarından farklı kılan özelliklerin bilimin din ve felsefe gibi sözel alanlardaki gibi direkt kabul etmek yerine, deney ve araştırma yaptığını ifade etmiştir. Öğretmen adayları bilimin gelişmesi, geçerli ve güvenilir bilgi elde edilmesi için bilimin deneye intiyaç duyduğunu ifade etmişlerdir. Büyük çoğunluğu da bilimsel deneylerden ve buluşlardan örnekler vererek bilimsel bilginin oluşmasında deneyin önemini desteklemeye çalışmışlardır. Öğretmen adayları bilimsel teorilerin zamanla değişebileceğine dair iddialarda bulunmuştur. Öğretmen adaylarının bir kısmı bilimsel yasa ve teori arasındaki fark ile ilgili olarak, uygulamadan önce olduğu gibi hala aralarında hiyerarşik bir ilişki olduğunu ve yasanın değiştirilemez olduğunu ifade etmektedirler. Ancak uygulamadan önceki cevaplarına göre uygulama sonrası cevaplarında öğretmen adaylarının bir kısmı genellikle değiştirilemeyeceğini ve yeni kanıtlar ışığında değişebileceğini söylemiştir. Öğretmen adayları tahmin, hipotez, deney ve gözlem sonuçlarına dayanarak emin olabildikleri iddiasında bulunmuşlardır. Öğretmen adayları bilim insanlarının türler hakkında araştırma yaparken türleri gözlemlediklerini, türlerin benzeyen özelliklerini kullandıklarını ve bunlara dayalı çıkarımlar ile türler hakkında emin olabildiklerini ifade etmişlerdir. Ayrıca türlerin çiftleştiklerinde verimli döl verip verememe özelliklerini dikkate aldıklarını söylemişlerdir. Öğretmen adayları bilim insanlarının aynı verileri kullanarak farklı sonuçlara ulaşma durumlarını bilim insanlarının önbilgileri arasındaki farktan, her bireyin farklı hayal gücüne sahip olmasıyla açıklamaya çalışmışlardır. Öğretmen adaylarının çoğunluğu bilimsel bilginin sosyal ve kültürel değerlerden ve içinde bulunduğu toplumun felsefi ve dini değerlerinden etkilendiğini ifade etmişlerdir. Ayrıca bilimin hayal gücü ve yaratıcılıktan etkilendiğini ifade etmişlerdir. Bu iddialarını ağırlıklı olarak Einstein ve Newton gibi bilim insanlarının buluşlarını ve icatlarını kullanarak örneklendirmeye çalışmışlardır. Aşağıda Tablo 5'de cevapları dikkat çeken ve anlaşılır olan 
öğrencilerin uygulama öncesi ve sonrası görüşleri verilmiştir.

Tablo 5.

ADBD Grubu Öğrencilerinin Uygulama Öncesi ve Sonrası Görüşlerinden Alıntılar

Uygulama öncesi görüşler

EE: “Bilim, gözlem ve gözleme dayalı akıl yürütme yoluyla dünyaya ilişkin olayları birbirine bağlayan yasaları bulma çabalarıdır. Diğer araştırmalardan ayıran en büyük özelliklerden biri deneye ve gözleme dayalı olmasıdır. Yani yaparak ve yaşayarak edilen bilgilerdir ve bilim sürekli değişen bir kavramdır."

FÖ: "Araştırma yaparak olayların neden sonuç ilişkisi araştıran, çözümler üreten, doğayı çevreyi anlamamızı sağlayan bilgilerin toplamıdır. Bilimi farkı yapan şey gözlem ve deneylerle bilginin toplanmasıdır."

EK: “Çünkü bilimsel bilginin gelişmesi için deneylere ihtiyaç vardır. Örneğin, Macellan Dünya'nın yuvarlak olduğunu deneyerek kanıtlamıştır. Newton başına elma düştüğünde yeni bir dizi deney yaparak bu düşüncesini kanıtlamıştır."

MU: "Deneylere ihtiyaç vardır. Bilimsel araştırmaların gelişebilmesi için deneyler yapılır. Deneyler olmazsa kesin görüşler olmaz. Ay’a gitmek mesela denemeden bilinemez."

\begin{abstract}
Uygulama sonrası görüşler
$\mathrm{H}$ : “Bilim, insanların doğayı, çevrelerini gözlemlemeleri sonucunda kabul gören düşüncelere aykırı bir bakış açısıyla yaklaşımları sonucu oluşan bir süreçtir. Bir fizik bilimiyle, din bilimi farklıdır. Fizikçi bir olayı doğrudan kabul etmez. O konuda deneyler ve araştırmalar yapar. Din biliminde deneye tabii olmayacak bazı kesin yargılar vardır."

S: "Bilim; merak ile olguların araştırılması, insanlık hayatını kolaylaştırmak için yapılan birçok konuyu içeren bir daldır. Bu olgular araştırıırken çeşitli deney ve gözlemlerden yararlanılır. Bir fizik dalını felsefe veya din dalından farklı yapan şey deneylere dayanmasıdır."
\end{abstract}

C: "Bilimsel bilginin gelişmesi için deneylere ihtiyaç vardır. Çünkü bilimsel bilgi olması için geçerli ve güvenilir bilgiler olmalıdır. Geçerli ve güvenilir bilgiler gözlemler yoluyla kesin bir şekilde elde edemeyeceğimiz için deneylere ihtiyaç vardır."

EK: "Bilimsel bilginin gelişmesi deneye ihtiyaç duyar. Çünkü Newton elmanın düşüşünden sonra cismin yere düşmesini yükseklikle ilgili olup olmadığını araştırmış. Daha sonra başka bir bilim insanı kilin içerisine kurşun topu farklı yüksekliklerden bırakarak bunu kanıtlamıştır."

CK: "Bilim insanları bilimsel bir teori geliştirdikten sonra teorileri değişebilir. Gezegenlerin sayısı 7 iken 6 oldu. Buradaki teori değişti. Çünkü teorilerin ortaya atıldığı zaman yapılan gözlemler veya çalışmalar tam olarak kesinleşmemiş olabilir. Ama günümüzdeki bilim insanları bunları daha hassas araçlarla yaparak kanıtlamış olabilirler."

HY: "Bilimsel teori, başka geçerliliği yüksek kanıtlarla değiştirilebilir. Evrim teorisi geçerliliği kanıtlanmış gibi gözükse de yapılan araştırmalarla değişebilir. Örneğin, Dünya'nın yuvarlak bir tepsi gibi olduğu teorisi değişmiştir."

BP: "Evet vardır. Evrim teorisi kanıtlanmamış ve hala tartışma halinde olan bir konudur. Kepler yasası ise dünyanın hareketiyle ilgili kanıtlanmış bir bilgi olup herkes tarafından kabul görmüştür."

FÖ: "Her ikisi de değişebilir. Yasa değişmez diye bilinir. Fakat yeni bilgilerle bunlar değişebilir. Newton'un birinci yasası ve atom teorisi buna örnektir."

DK: "Evet fark vardır. Bilimsel bir yasa genellikle değişmez. Örneğin Newton'un hareket kanunları her zaman her koşulda kesindir. Bilimsel bir teori geliştirilebildiği gibi çürütülebilir. Örneğin, ışık hızını geçen bir parçacığın bulunduğu söylemiyiz." 
DK: “Bilim insanları atomun yapısı hakkında karar verirken birçok çalışmalar yapmışlardır ve bu çalışmalar hep bir aşamalı şekilde ilerlemiştir. Önceleri boş bir küreye benzetilen atom üzümlü kek modeli güneş sistemi modeline de benzetilmiştir. Yapılan her bir çalışma atom hakkındaki bilimsel bilginin gelişmesine katkıda bulunmuştur. Maddelerin özel durumlarında yararlanılarak çalışmalar yapılmıştır."

Y: "Atomun yapısı ile ilgili uzun yıllar boyunca araştırmalar yapılmıştır. Atomun yapısı tahmin ile ortaya çıkmıştır. En başta bilim adamları elektronların hareketli olabileceklerini hayal ederek başlamış daha sonra deneylerle bunu desteklemiştir. Bilim adamları atomun şeklini proton, nötron ve elektronların yüklerinden dolayı bulmuşlardır. Bu taneciklerin hareketlerinden yola çıkmışlardır."

DK: "Bilim insanları bu konuda gözlemler yapıp çiftleşen grubun verimli döl verdiğini diğer grubun ise vermediğini görmüşlerdir. Yapılan çalışmalar sonucunda çıkan durumlara göre yorumlamışlardır. Karar verirken canlının yapısını, genlerini ve verdiği döllerden yararlanmışlardır."

CS: "Deneyler yapmışlardır. Örneğin, eşek ile ata aynı tür kabul ederek çiftleştiklerinde meydana gelen yavru verimsiz olduğunu gözlemleriz. Bilim adamları da varsayımlardan denemelerden yola çıkıyor."
HY: "Bilimsel olarak öne sürülen teorileri deneyler ve gözlemler yaparak bilimsel bir yasaya getirmişlerdir. Tabii bu öneri kendileri arasında yaptıkları deneyler soncunda oluşmuştur. Bu kadar emin olabilmektedir. Proton ve nötronların merkezdeki bir çekirdek bir çekirdek ile etrafından dolaşan elektronların oluştuğu bilgileri kullanmışlardır."

TA: "Yaptıkları deneyler, varsayımlar, gözlemler, kurdukları hipotezler sayesinde emin olabilmektedirler. Sonuçta ellerinde somut bilgiler vardır. Doğru veya yanlış ispat etme şansları bulunmaktadır."
YY: "Bunu hayvanları çiftleştirerek öğrenmiş olabilirler. Çünkü türler kendi aralarında verimli döl alışverişi yapabilirler. At ve eşek birbirinden ayrı türlerdir ve çiftleştiklerinde doğan canlı katırdır. Katır kısır bir hayvandır. Burada verimli döl alışverişi olmamıştır. Bilim adamları mantık ve bir dizi deneyler tür kavramını açıklamıştır."

BK: "Verimli dölleri hangi türlerin verdiği birçok deneyle öğrenilmeye çalışılmıştır ve bu şekilde birbirine benzer organizmaların ancak kendi türleriyle verimli döl verecekleri anlaşılmıştır. Bütün organizmaların gen haritalarına bakılarak özellikleri ortaya çıkarılabilir ve hangi türün hangi türle verimli döl verdiği sonucuna varılabilir."

AE: "Bilim insanlarının farklı teorileri olduğunu söyleyebiliriz. Hipotezlerin aynı verilere ulaşıp farklı sonuçların oluşması bu bilim adamlarının yaşadıkları yer, kültür, çalışma ortamı, düşünce tarzında bağlı olabilir." SA: "Çünkü herkesin düşündüğü elde etmek için uğraştığı fikir farklıdır ve kesin eskiden bilim bu kadar gelişmediği için bu farklılıklar olmaktadır. Kesin sonuçlar, kanıtlar eskisi kadar iyi değildir."
YY: "Özellikle herkesin tahmini ve hayal gücü birbirinden farklıdır. ìki grupta da farklı öngörüler mevcuttur. Iki hipotez de dinozorların Dünya'dan nasıl yok olduğunu ifade etmektedir."

TA: "Yorumlamalardan dolayı farklılıklar oluşur. Sonuçta bu fikirleri ortaya atan bilim insanlarının düşünce ve yorumlama yetenekleri birbirlerinden farklıdır. Yine bulundukları ortam ve şartlarda bunda etkilidir. Kimisi fikrini rahat bir ortamda ortaya atabilirken kimisi ise belirli otoriteye bağlı olarak kalmak zorunda kaldığı için (orta çağ zamanındaki bilim) bu tarz düşünceler ortaya atabilir." 


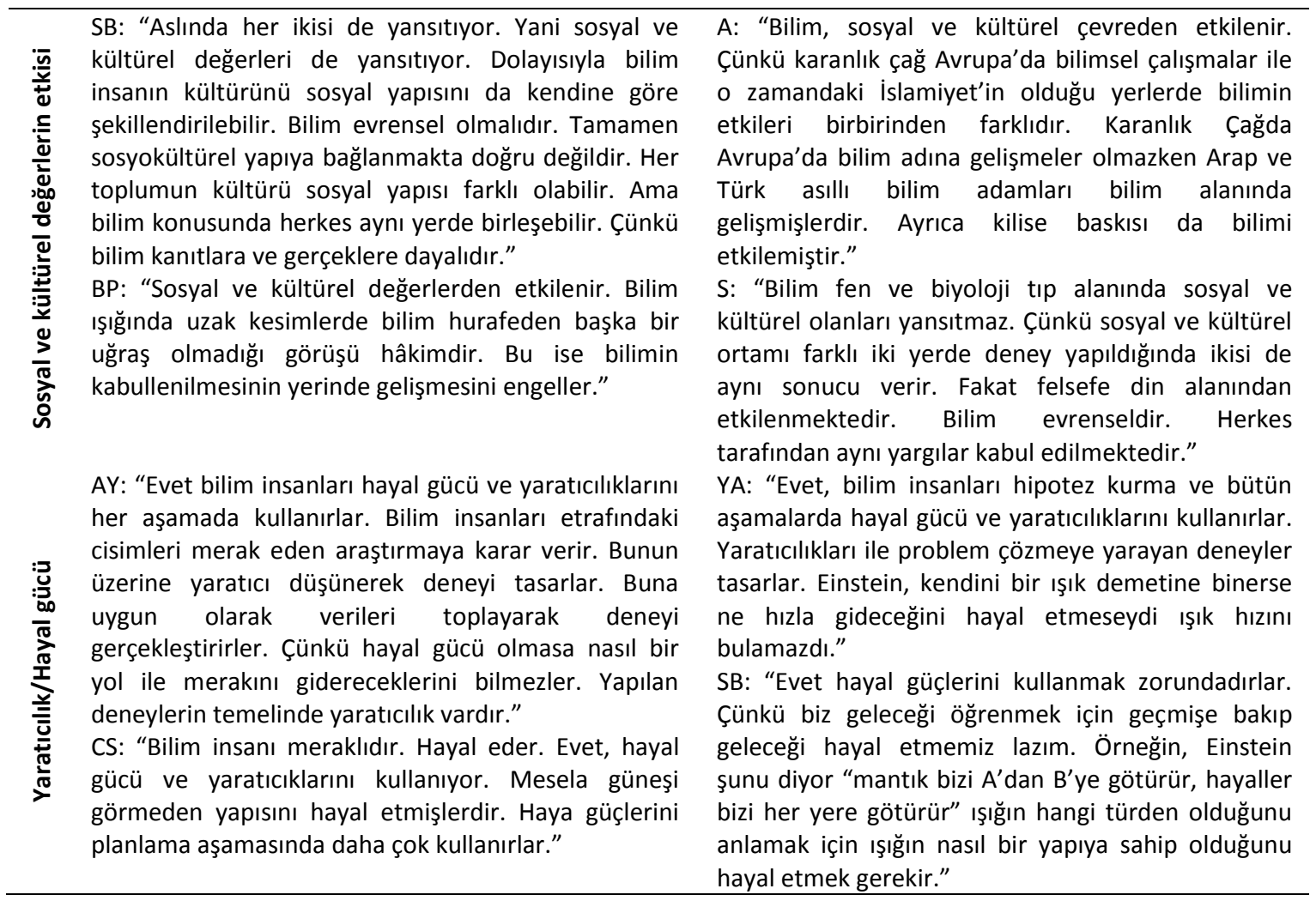

\section{Sonuç, Tartışma ve Öneriler}

Argümantasyon fen sınıflarındaki söylemlerin analiz ve yorumlanmasının etkili bir yolu olarak görülmektedir. Derslerde bilimsel argümantasyonun kullanılması öğrencilerin ve öğretmenlerin bilimsel bilgi iddialarını değerlendirmesi ve oluşturmasına yardımcı olur (Duschl, 2007). Benzer şekilde bu çalışmada öğretmen adaylarının bilimin doğasına yönelik görüşlerini ifade ettikleri yazılı argümanlarını nasıl oluşturdukları ve aldıkları farklı bilimin doğası öğretimlerinin kavramsal anlamalarına nasıl yansıdığı incelenmiştir. Öğretmen adaylarının bilimin doğasına ilişkin görüşlerini ifade etmek için oluşturdukları yazılı argümanlar Türkçe argümantasyon modeli (Aktamış \& Hiğde, 2015) temel alınarak değerlendirilmiştir. Çünkü deney grubundaki öğretmen adayları ders sürecinde bu model temel alınarak bilimin doğasına ilişkin argümantasyon destekli açık düşündürücü bilimin doğası öğretimine katılmışlardır.

Öğretmen adaylarının bilimin doğasına yönelik görüşlerini ifade ettikleri yazılı argümanları iddia, kanıt (veri ve akıl yürütme), destekleyici ve çürütücü bileşenleri bakımından incelenmiştir. Öğretmen adaylarının uygulama öncesinde bilimin doğasına yönelik yazılı argümanlarının zayıf olduğu ancak uygulama sonrasında güçlü argüman kurma becerisi gelişen birçok öğretmen adayı olduğu görülmektedir. Bu sonucun yalnızca öğretmen adaylarının argümantasyon destekli bir öğretime katılarak güçlü argümantasyon kurmayı öğrenmeleriyle değil bilimin doğası hakkındaki epistemolojik bilgilerinin gelişmesiyle ilişkili olduğu birçok araştırmacı tarafından ifade edilmiştir (Bell \& Lederman, 2003; Sandoval, 2003; McDonald, 2010).

ADADBD eğitimi alan öğretmen adaylarının uygulama öncesinde iddiaları için kanıt sağlayamadıkları ama uygulama sonrasında katılımcıların yarısından fazlasının güçlü kanıtlar oluşturabildiği, sadece az sayıda katılımıının kanıt sağlayamadığı görülmektedir. ADBD etkinliklerine katılan katılımcıların ise genellikle zayıf kanıtlar sağlayabildikleri görülmektedir.

Öğretmen adaylarının akıl yürütme becerilerini kullanarak uygun verileri kanıt olarak sunmada 
aldıkları açık düşündürücü argümantasyon destekli ve sadece açık düşündürücü bilimin doğası öğretiminin etkili olduğu görülmüştür. Argümantasyon destekli eğitim alan gruptaki katılımcıların güçlü kanıtlar sağlarken diğer gruptakilerin zayıf kanıtlar sunmuş olması argümantasyon destekli eğitim alanların açık düşündürücü yaklaşımdan ve bilim tarihi içeren örneklerden etkilenmiş olabileceği söylenebilir. Çünkü argümantasyon destekli eğitim alan gruptakilerin daha fazla ve bilim tarihine dayanan çeşitli kanıtlar sağlayabildiği ve kanıtlarını zenginleştirdiği görülmektedir. Ek olarak açık düşündürücü yaklaşımın uygulanması ve bilimin tarihi ile ilgili konularda bilimin gelişiminin nasıl olduğunun tarihteki bilimsel olaylarla birlikte ele alınmasının kanıt kullanmayı geliştirdiği ancak kullanılan kanıtların istenen seviyede olmadığı görülmektedir. Buna paralel olarak McDonald (2010) yaptığı çalışmada öğretmen adaylarının açık düşündürücü bilim doğası ve argümantasyon öğretiminin sonucunda uygun verileri kullanarak kanıt sağlayabildiklerini ortaya çıkarmıştır.

Argümantasyon destekli eğitim alanların sadece açık düşündürücü bilimin doğası dersi alanlara göre daha fazla güçlü veri sağlayabildikleri ve açık düşündürücü bilimin doğası eğitimi alanların çok azının gelişim göstererek zayıf veri sağlayabildiği görülmektedir. Argümantasyon destekli gruptakilerin güçlü veriler sunmadaki gelişimleri bilim tarihindeki örnekleri ve deneysel verileri uygun şekilde kendi iddialarını desteklemek için kullanabilmeleriyle açıklanabilmektedir. Bilimin doğasına yönelik veri sağlayabilmeleri uygulamada katıldıkları argümantasyon destekli etkinliklerde bilim tarihinden ve bilimsel bilginin oluşumuyla ilgili örnekler hakkında bilgilerinin gelişmesi ile bağdaştırılabilir (Sandoval, 2003). Ayrıca öğretmen adaylarının sağladıkları verilerin çoğunda katıldıkları uygulamada öğrendikleri örnekleri kullanmaları gösterilebilir (Khishfe, 2014).

Destekleyici sağlamada argümantasyon destekli eğitim alan öğretmen adaylarının çok az gelişim gösterirken ADBD alan katılımcılar hiçbir gelişim gösterememiştir. Çürütücü oluşturmada da her iki gruptakilerin hiçbir gelişim gösteremedikleri görülmüştür. Bunun sebebi olarak öğretmen adaylarının argümantasyon destekli bir derse ilk kez katılmaları, yazılı argümantasyonda çürütücü sağlamanın zor olması, öğrencilerin argümantasyon hakkındaki ön öğrenmelerinin olmayışı, destekleyici ve çürütücü sağlayacak kadar bilimin doğasına yönelik bilgilerinin gelişmiş olmaması olabilir (Kelly ve diğ., 2008). Ek olarak öğretmenlerin fen sınıflarında argümantasyon uygulama deneyimlerinin eksikliği ve pedagojik olarak argümantasyon uygulama becerilerinin eksikliği olarak görülmektedir (Driver, Newton \& Osborne, 2000). Alan yazına bakıldığında birçok çalışmada öğretmen adayları ve öğrencilerin bilimsel konulara farklı açılardan ve çoklu bakış açısıyla bakmalarının gerekliliğine vurgu yapılmıştır (Yang \& Anderson, 2003). Ancak yapılan çalışmaların sonuçları bu çalışma sonuçlarıyla tutarlı şekilde öğretmen adayı ve öğrencilerin bilimsel konuları farklı açılardan değerlendirmedeki eksikliklerinden dolayı ileri seviyede argüman kuramadıkları ve akıl yürütme yapamadıklarını göstermektedir (Demircioğlu \& Uçar, 2014). Bu çalışmanın bulguları ışığında fen bilgisi öğretmen adaylarının ADADBD öğretimi almalarının bilimin doğasına yönelik yazılı argümanlarını üst derece olmasa da orta seviyede geliştirdiği görülmektedir. Benzer şekilde okullarda argümantasyon kalitesinin artırılmasına yönelik yapılan iki buçuk yıllık proje çalışmasında öğretmenlerin orta düzeyde argümantasyon geliştirebildikleri görülmüştür (Erduran, Simon \& Osborne, 2004). Bu proje çalışmasının süresi ile ADADBD çalışmasının süreleri karşılaştırıldığında öğretmen adaylarıyla yapılan ADADBD öğretiminin üç ay gibi kısa bir süre içinde gerçekleşmiş olması önemli bir kısıtlama olarak görülebilir. Öğretmen adaylarının üst derecede yani geliştirdikleri argümanlara daha fazla destekleyici sağlayabilmeleri ve çürütme bileşenlerini de kullanabilmeleri için bilime yönelik kavramsal ve epistemik bakış açılarını geliştiren, bilimin doğasına yönelik üst bilişsel farkındalıklarını artıran etkinliklere katılmaları önerilmektedir. Öğretmen adaylarına bilimin doğasına yönelik direkt sorular yerine argümantasyon bileşenlerini ayırt edebilecekleri ve nasıl bu bileşenleri kullanabileceklerini örnekleyen hazır bileşenlerin (iddia, veri, kanıt, destekleyici ve çürütme) verildiği etkinlikler uygulanarak argümantasyonda bilimin doğasına yönelik görüşlerini gerekçelendirmelerine yardımcı olunabilir. Öğretmen adaylarıyla yapılan bu çalışma ortaokul ve lise seviyesindeki öğrenciler ile de test edilebilir. Bu çalışma bilimin doğası ve argümantasyonun bir arada çalışıldığı çalışmalar için deneysel bir destek sağlarken, gerçekten öğretmen adaylarının kendi sınıflarında bilimin doğası ve argümantasyonu nasıl uyguladıklarına yönelik çalışmaların yapılması önerilmektedir. 


\section{References}

Abd-El-Khalick, F., Bell, R.L., \& Lederman, N.G. (1998). The nature of science and instructional practice: Making the unnatural natural. Science Education, 82, 417-436.

Abd-El-Khalick, F., \& Lederman, N.G. (2000). Improving science teachers' conceptions of nature of science: A critical review of the literature. International Journal of Science Education, 22 (7), 665701.

Aktamış, H. ve Hiğde, E. (2015). Fen Eğitiminde Kullanılan Argümantasyon Modellerinin Değerlendirilmesi. Mehmet Akif Ersoy Üniversitesi Eğitim Fakültesi Dergisi, 35, 136 - 172.

American Association for the Advancement of Science (AAAS). (1993). Benchmarks for science literacy: A Project 2061 report. New York: Oxford University Press.

Bell, R.L. (2009). Teaching the Nature of Science: Three Critical Questions. Carmel, CA: National Geographic School Publishing.

Bell, R.L., \& Lederman, N.G. (2003). Understandings of the nature of science and decision making on science and technology based issues. Science Education, 87, 352-377.

Bell, P., \& Linn, M.C. (2000). Scientific arguments as learning artifacts: Designing for learning from the web with KIE. International Journal of Science Education, 22(8), 797-817.

Campbell, D. T. \& Stanley, J. C. (1963). Experimental and Quasi-Experimental Designs for Research. Chicago: Rand McNally.

Çetin, P., S. (2014). Explicit argumentation instruction to facilitate conceptual understanding and argumentation skills. Research in Science and Technological Education, 32(1), 1-20.

Demircioğlu, T. veUçar, S. (2014). Investigation of written arguments about akkuyu nuclear power plant. Elementary Education Online, 13(4), 1373-1386.

Doğan, N., Çakıroğlu, J., Bilican, K. veÇavuş, S. (2012). BiliminDoğasıveÖğretimi. Ankara. PegemAkademi.

Driver, R., Newton, P., \& Osborne, J. (2000). Establishing the norms of scientific argumentation in classrooms. Science Education, 84, 287-312.

Duschl, R. A., (2007). Quality argumentation and epistemic criteria. In S. Erduran, and M. P. JiménezAleixandre (Eds.), Argumentation in science education: Perspectives from classroom-based research (pp. 159-175). Dordrecht, The Netherlands: Springer.

Erduran, S., Simon, S., \& Osborne, J. (2004). TAPping into argumentation: Developments in the application of Toulmin argument pattern for studying science discourse. Science Education, 88, 915933.

Jiménez-Aleixandre, M. P., \& Erduran, S. (2007). Argumentation in science education: An overview. In S. Erduranve M. P. Jiménez-Aleixandre (Editörler), Argumentation in science education: Perspectives from classroom-based research (pp.3-27). Dordrecht, The Netherlands: Springer.

Newton, P., Driver, R. ve Osborne, J. (1999). The place of argumentation in the pedagogy of school science. International Journal of Science Education, 21 (5), 553-576.

Jimenez-Aleixandre, M.P., Rodriguez, A.B., \& Duschl, R.A. (2000). "Doing the lesson" or "doing science": argumentation in high school genetics. Science Education, 84, 757-792.

Kelly, G.J., Regev, J., \& Prothero, W. (2008). Analysis of lines of reasoning in written argumentation. In Erduran, S. and Jimenez-Aleixandre, M.P. (eds.), Argumentation in Science Education (p. 137-157). Springer. 
Khishfe, R. (2012).Relationship between nature of science understandings and argumentation skills: A role for counterargument and contextual factors. Journal of Research in Science Teaching, 49(4), 489514.

Khishfe, R. (2014). Explicit Nature of Science and Argumentation Instruction in the Context of Socioscientific Issues: An effect on student learning and transfer. International Journal of Science Education, 36(6), 974-1016.

Khishfe, R., \&Abd-El-Khalick, F. (2002). Influence of explicit and reflective versus implicit inquiry-oriented instruction on sixth graders' views of nature of science. Journal of Research in Science Teaching, 39, 551-578.

Küçük, M. (2006). Bilimin doğasını ilköğretim 7. Sınıf öğrencilerine öğretmeye yönelik bir çalışma. Yayınlanmamış Doktora Tezi, Karadeniz Teknik Üniversitesi, Fen Bilimleri Enstitüsü, Trabzon.

Köseoğlu, F, Tümay, H. \& Budak, E. (2008). Bilimin doğası hakkında paradigm değişimleri ve öğretimi ile ilgili yeni anlayışlar. GÜ, Gazi Eğitim Fakültesi Dergisi, 28(2), 221-237.

Lederman, N. G. (2007). Nature of science: Past, present, and future. In S.K. Abell, and N.G. Lederman, (Editors), Handbook of research in science education (pp 831-879). Mahwah, New Jersey: Lawrence Erlbaum Publishers.

Lederman, N.G. (1992). Students' and teachers' conceptions of the nature of science: A review of the research. Journal of Research in Science Teaching, 29(4), 331-359.

Lederman, N. G., \& Abd-El-Khalick, F. (1998). Avoiding de-natured science: Activities that promote understanding of the nature of science (83-126). In McComas (Ed.) The Nature of Science in Science Education: Rationales and Strategies. The Netherlands: Kluwer Academic Publishers

Lederman, N. G., Abd-El-Khalick, F., Bell, R. L., \& Schwartz, R. S. (2002).Views of The nature of science Questionaire: Toward valid and meaningful assessment of learners" conceptions of the nature of science. Journal of Research in Science Teaching, 39(6), 497-521.

McDonald, C.V. (2008). Exploring the influence of a science content course incorporating explicit nature of science and argumentation instruction on preservice primary teachers' views of nature of science. Unpublished Doctoral Dissertation, Queensland University of Technology, Brisbane, Australia.

McDonald, C., V. (2010). The Influence of Explicit Nature of Science and Argumentation Instruction on Preservice Primary Teachers' Views Of Nature Of Science. Journal Of Research In Science Teachıng, 47(9), 1137- 1164.

McDonald, C.V., \& McRobbie, C.J. (2011). Utilising argumentation to teach nature of science. In B.J. Fraser, K. Tobin, and C. McRobbie (Eds.), Second international handbook of science education. Dordrecht: Springer.

Milli Eğitim Bakanlığı [MEB]. (2013) Fen Bilimleri Dersi Öğretim Programı (3.- 8. sınıflar). Milli Eğitim Bakanlığı Yayınları, Ankara, 2013.

McComas, W. F. (2004). Keys to teaching the nature of science: Focusing on the Nature of Science in the Science Classroom. The Science Teacher, 71 (9), 24-27.

McComas, W. F. \& Olson, J.K. (1998). The Nature of Science in International Science Education Standards Documents. In McComas (Ed.) The Nature of Science in Science Education: Rationales and Strategies, Kluwer Academic Publishers: The Netherlands. pp. 41-52.

National Research Council. (1996). National science education standards. Washington, DC: National Academy Press. 
Ogunniyi, M.B. (2006). Using an argumentation-instrumental reasoning discourse to facilitate teachers' understanding of the nature of science. Paper Presented at the Annual Meeting of the National Association for Research in Science Teaching (NARST), San Francisco, CA.

Sadler, T.D., Chambers, F.W., \& Zeidler, D. L. (2004). Student conceptualisations of the nature of science in response to a socioscientific issue. International Journal of Science Education, 26(4), 387-409.

Sampson, V. \& Clark, D. B. (2008). Assessment of the Ways Students Generate Arguments in Science Education: Current Perspectives and Recommendations for Future Directions. Science Education. 92, 447-472.

Sandoval, W. A. (2003). Conceptual and Epistemic Aspects of Students' Scientific Explanations. Journal of the Learning Sciences, 12(1), 5-51.

Sandoval, W.A., \& Millwood, K.A. (2007). What can argumentation tell us about epistemology? In S. Erduran and M.-P. Jimenez-Aleixandre (Eds.), Argumentation in science education: Perspectives from classroom-based research (pp. 71-88). Dordrecht: Springer.

Schwartz, R. S., Lederman, N. G., \& Crawford, B. A. (2004). Developing views of nature of science in an authentic context: An explicit approach to bridging the gap between nature of science and scientific inquiry. Science Education, 88 (4), 610-645.

Toulmin, S. E. (2003). The uses of argument (Updated ed.). Cambridge: Cambridge University Press.

Walker, K. A., \& Zeidler, D. L. (2004). The role of students' understanding of the nature of science in a debate activity: Is there one? Paper Presented at the Annual Meeting of the National Association for Research in Science Teaching (NARST), Vancouver, BC, Canada.

Yang, F.Y. \& Anderson, O. R. (2003). Senior high school students' preference and reasoning modes about nuclear energy use. International Journal of Science Education, 25(2), 221 - 244.

Yerrick, R. K. (2000). Lower track science students' argumentation and open inquiry instruction. Journal of Research in Science Teaching, 37(8), 807-838.

Yore, L.D., Florence, M.K., Pearson, T.W., \& Weaver, A.J. (2006). Written discourse in scientific communities: A conversation with two scientists about their views of science, use of language, role of writing in doing science, and compatibility between their epistemic views and language. International Journal of Science Education, 28, 109-141.

Zohar, A., \& Nemet, F. (2002). Fostering students' knowledge and argumentation skills through dilemmas in human genetics. Journal of Research in Science Teaching, 39(1), 35-62. 